ZOOLOGIA 27 (4): 503-522, August, 2010

doi: $10.1590 /$ S1984-46702010000400003

\title{
Altitudinal distribution of birds in a mountainous region in southeastern Brazil
}

\author{
Francisco Mallet-Rodrigues ${ }^{1}$; Ricardo Parrini'; Leonardo M. S. Pimentel ${ }^{3} \&$ Rafael Bessa ${ }^{4}$
}

\author{
${ }^{1}$ Laboratório de Ornitologia, Departamento de Zoologia, Instituto de Biologia, Universidade Federal do Rio de Janeiro. \\ 21944-970 Rio de Janeiro, RJ, Brazil.E-mail: fmallet@bol.com.br \\ ${ }^{2}$ Rua Desembargador Isidro 160, ap. 601. 20521-160 Rio de Janeiro, RJ, Brazil. E-mail: rparrini@hotmail.com \\ ${ }^{3}$ Reserva Ecológica de Guapiaçu. 28680-000 Cachoeiras de Macacu, RJ, Brazil. E-mail: savatta@bol.com.br \\ ${ }^{4}$ Rua Lucídio Lago 389, ap. 403. 20780-020 Rio de Janeiro, RJ, Brazil. E-mail: rafabessa@msn.com
}

\begin{abstract}
We studied the altitudinal distribution of 426 bird species in the Serra dos Órgãos, a mountainous region in southeastern Brazil. Thirty-four localities were visited between 1991 and 2009. Our study revealed a decline in bird species richness with elevation, although a smaller number of species was recorded at lower altitudes (below $300 \mathrm{~m}$ ) possibly due to local extinctions caused by the intense human occupation of the region. A less diverse avifauna was found above 2,000 m, with only one species (Caprimulgus longirostris) recorded exclusively in this altitudinal range. Most endemic species were found between 300 and 1,200 m, but the endemism was more significant at higher altitudes. Nearly half of the birds found above 1,400 m were endemic species. Most of the threatened species from the state of Rio de Janeiro recorded in our study were found below 1,200 m, but no significant difference was found between the proportions of threatened species among different altitudinal ranges. Species of seventeen genera have exhibited some replacement (sometimes with partial overlap) along altitudinal gradients.
\end{abstract}

KEY WORDS. Atlantic Forest; avifauna; birds; elevational distribution.

The distribution of bird species and other organisms in mountainous regions usually vary according to different altitudinal ranges. Changes in the composition of bird species in an altitudinal gradient have been explained by various factors such as: the influence of physical and biological conditions varying along altitudinal gradients; the competition among bird species; and the habitat discontinuities (ecotones), among other factors (Terborgh 1971, 1977, Noon 1981, Loiselle \& BlaKe 1991, Navarro 1992, Lomolino 2001).

Few studies have reported the patterns of altitudinal distribution of birds in the mountains of southeastern Brazil. A pioneering study was conducted in the Itatiaia massif (Holt 1928). In that study, the bird species were distributed in three altitudinal ranges (life zones) - tropical, subtropical and temperate. Later, other studies also focused on the patterns of bird distribution along altitudinal gradients in mountains of southeastern (SCott \& BRooke 1985, Goerck 1999, Buzzetti 2000, RajÃo \& Cerqueira 2006) and southern Brazil (Bencke \& Kindel 1999).

Based on ornithological surveys undertaken between 1991 and 2009 in various localities of the Serra dos Órgãos, southeastern Brazil, this study aims to identify the altitudinal ranges of each bird species found in the region, the species richness and the proportion of Atlantic Forest endemic and threatened bird species along altitudinal gradients. Local patterns of altitudinal replacement by closely related species are also discussed.

\section{MATERIAL AND METHODS}

The Serra dos Órgãos, a majestic mountainous region with higher elevations nearing 2,200 m, belongs to the Serra do Mar massif and is located in the central region of the state of Rio de Janeiro. The Atlantic Forest, the main ecosystem which still remains in several areas of this region, is subdivided into the following formations according to altitude: lowland forest (up to $50 \mathrm{~m}$ ), submontane forest $(50-500 \mathrm{~m})$, montane forest (500$1,500 \mathrm{~m})$ and high-montane forest (1,500-1,900 m). High grasslands occur on altitudes above 1,900-2,000 m and are concentrated predominantly in areas within the Parque Nacional da Serra dos Órgãos (Radambrasil 1983, Veloso et al. 1991, Amador 1997).

The lowland forest was the first habitat to be destroyed during the human occupation of the region and is not presently intact in the Serra dos Órgãos (AMADOR 1997). Submontane and montane forests were more preserved than the lowland forest. The high-montane forest was best preserved during the process of occupation in the region, and its most significant remaining areas are in the Parque Nacional da Serra dos Órgãos, and in the Parque Estadual dos Três Picos.

Ornithological records from several localities in the Serra dos Órgãos were used here (Fig. 1). We visited areas of lowland, submontane, montane and high-montane forests, high grasslands, second growth, swamps, wetlands, pastures and urban 


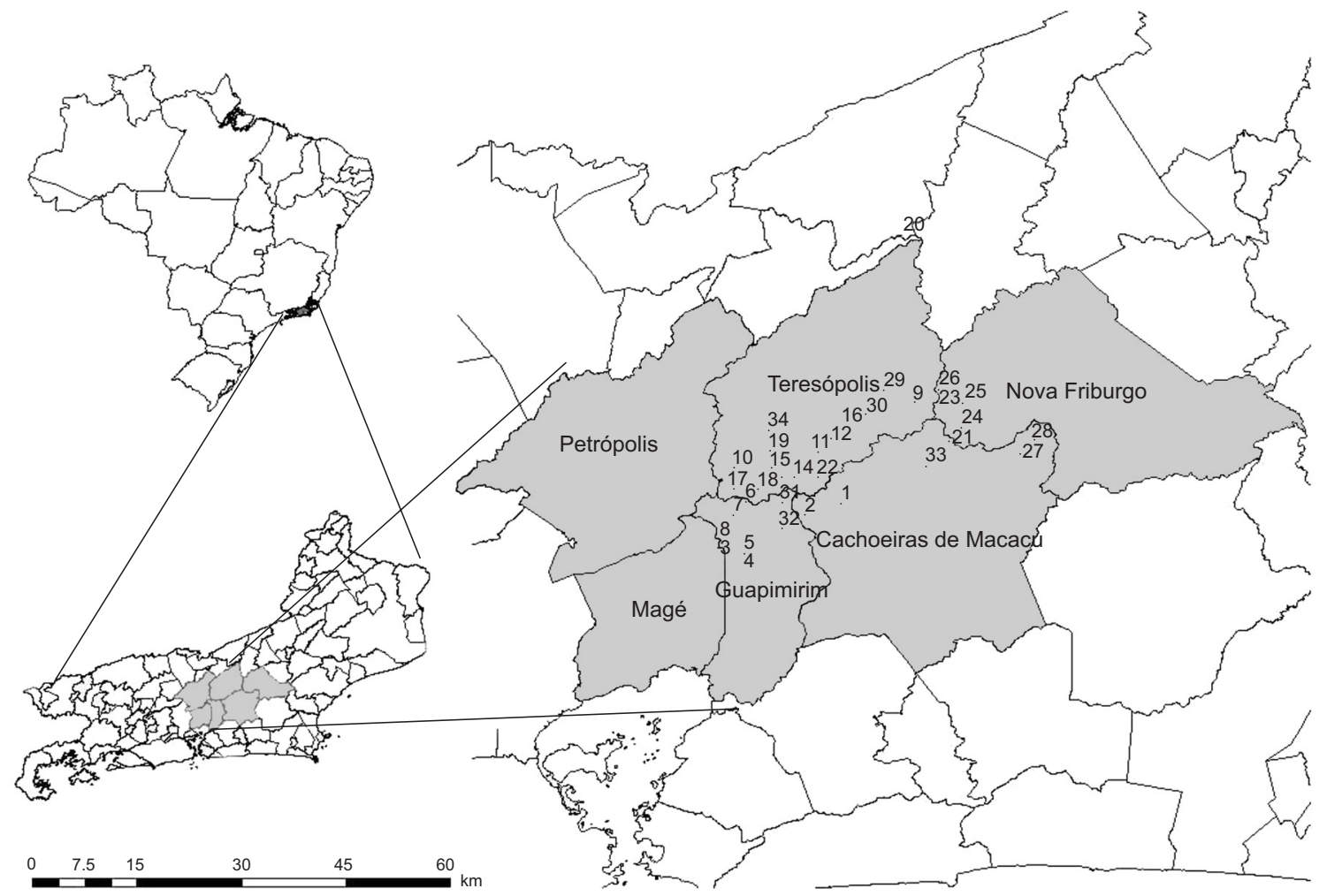

Figure 1. Map of the Serra dos Órgãos region showing study localities and municipalities. Numbers represent the localities (see Material and Methods).

environments, located in permanently protected areas (Parque Nacional da Serra dos Órgãos, Parque Estadual dos Três Picos, Estação Ecológica Paraíso, Reserva Ecológica de Guapiaçu) or outside of them. The following localities were visited during our study: 1) Sitio Rosemary and Serra Queimada $\left(22^{\circ} 28^{\prime} \mathrm{S}\right.$, $42^{\circ} 51^{\prime} \mathrm{W} ; 0-200 \mathrm{~m}$ ), municipality of Cachoeiras de Macacu (lowland forest, submontane forest and second growth); 2) Estação Ecológica Paraíso and Centro de Primatologia $\left(22^{\circ} 29^{\prime}\right.$ S, $42^{\circ} 54^{\prime} \mathrm{W}$; 0-200 m), municipality of Guapimirim (lowland forest, submontane forest and second growth); 3) Corujas ( $22^{\circ} 31^{\prime} \mathrm{S}$, $43^{\circ} 01^{\prime} \mathrm{W}$; 200-400 m), municipality of Guapimirim (submontane forest and second growth); 4) Casa de Viseu (22 $32^{\prime} \mathrm{S}$, $42^{\circ} 59^{\prime} \mathrm{W}$; 0-150 m), municipality of Guapimirim (submontane forest, second growth and swamps); 5) City of Guapimirim and vicinity $\left(22^{\circ} 32^{\prime} \mathrm{S}, 42^{\circ} 59^{\prime} \mathrm{W}\right.$; 0-200 m), municipality of Guapimirim (submontane forest, second growth, urban area and swamps); 6) Garrafão (22 $28^{\prime} \mathrm{S}, 42^{\circ} 59^{\prime} \mathrm{W}$; 300-700 m), municipality of Guapimirim (submontane forest, montane forest and second growth); 7) Headquarters of Guapimirim of the

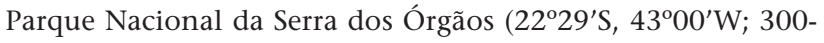
$500 \mathrm{~m}$ ), municipality of Guapimirim (submontane forest and second growth); 8) Monte Olivete (22 $31^{\prime} \mathrm{S}, 43^{\circ} 01^{\prime} \mathrm{W} ; 200-400$ $\mathrm{m})$, municipality of Guapimirim (submontane forest, second growth and swamps); 9) Frades $\left(22^{\circ} 20^{\prime} \mathrm{S}, 42^{\circ} 45^{\prime} \mathrm{W}\right.$; 900-1,000 $\mathrm{m})$, municipality of Teresópolis (montane forest, second growth, pasture and swamps); 10) Headquarters of Teresópolis of the Parque Nacional da Serra dos Órgãos (22 $26^{\prime}$ S, $43^{\circ} 00^{\prime} \mathrm{W}$; 900$1,100 \mathrm{~m}$ ), municipality of Teresópolis (montane forest and second growth); 11) Canoas ( $22^{\circ} 24^{\prime} \mathrm{S}, 42^{\circ} 53^{\prime} \mathrm{W}$; 800-950 m), municipality of Teresópolis (montane forest, second growth and swamps); 12) Fazenda da Floresta ( $22^{\circ} 23^{\prime} \mathrm{S}, 42^{\circ} 52^{\prime} \mathrm{W}$; 800-980 $\mathrm{m})$, municipality of Teresópolis (montane forest and second growth); 13) Fazenda Vale da Revolta $\left(22^{\circ} 26^{\prime} \mathrm{S}, 42^{\circ} 56^{\prime} \mathrm{W}\right.$; 850$1,040 \mathrm{~m}$ ), municipality of Teresópolis (montane forest, second growth and swamps); 14) Área de Proteção Ambiental do Jacarandá $\left(22^{\circ} 26^{\prime} \mathrm{S}, 42^{\circ} 55^{\prime} \mathrm{W}\right.$; $\left.900-1,080 \mathrm{~m}\right)$, municipality of Teresópolis (montane forest, second growth, wetlands and swamps); 15) Serra do Cavalo (22 $26^{\prime} \mathrm{S}, 4^{\circ} 2^{\circ} 57^{\prime} \mathrm{W}$; 900-1,100 $\mathrm{m})$, municipality of Teresópolis (montane forest and second growth); 16) Alto da Posse $\left(22^{\circ} 22^{\prime} \mathrm{S}, 42^{\circ} 51^{\prime} \mathrm{W}\right.$; 900-1,300 m), municipality of Teresópolis (montane forest, second growth and pasture); 17) Pedra do Sino trail ( $22^{\circ} 27^{\prime} \mathrm{S}, 43^{\circ} 00^{\prime} \mathrm{W} ; 1,200-$ 2,100 m), Parque Nacional da Serra dos Órgãos, municipality of Teresópolis (montane forest, high-montane forest and high grassland); 18) Comary (22 $22^{\prime} \mathrm{S}, 42^{\circ} 58^{\prime} \mathrm{W}$; 900-1,000 m), municipality of Teresópolis (montane forest, second growth 
and urban area); 19) City of Teresópolis $\left(22^{\circ} 24^{\prime} \mathrm{S}, 42^{\circ} 57^{\prime} \mathrm{W} ; 800\right.$ $980 \mathrm{~m}$ ), municipality of Teresópolis (second growth and urban area); 20) Serra do Capim (22 $07^{\prime} \mathrm{S}, 42^{\circ} 46^{\prime} \mathrm{W}$; 900-1,000 m), municipality of Teresópolis (second growth, pasture and swamps); 21) Trail between Fazenda Santo Antonio and Fazenda Campestre $\left(22^{\circ} 23^{\prime} \mathrm{S}, 42^{\circ} 42^{\prime} \mathrm{W}\right.$; 380-700 m) within the Parque Estadual dos Três Picos, municipalities of Cachoeiras de Macacu and Nova Friburgo (montane forest); 22) Clube Sayonara (22 $\left.26^{\prime} \mathrm{S}, 42^{\circ} 53^{\prime} \mathrm{W} ; 900 \mathrm{~m}\right)$, Serra do Subaio, Parque Estadual dos Três Picos, municipality of Teresópolis (montane forest and second growth); 23) Três Picos de Salinas $\left(22^{\circ} 19^{\prime} \mathrm{S}, 42^{\circ} 43^{\prime} \mathrm{W}\right.$; 1,550-1,750 m), Parque Estadual dos Três Picos, municipalities of Teresópolis and Nova Friburgo (high-montane forest, second growth, wetland and swamps); 24) Fazenda Campestre $\left(22^{\circ} 22^{\prime} \mathrm{S}, 42^{\circ} 41^{\prime} \mathrm{W} ; 1,050-1,100 \mathrm{~m}\right)$, municipality of Nova Friburgo (montane forest, second growth and pasture); 25) Mariana $\left(22^{\circ} 20^{\prime} \mathrm{S}, 42^{\circ} 41^{\prime} \mathrm{W} ; 1,300 \mathrm{~m}\right)$, municipality of Nova Friburgo (montane forest, second growth and pasture); 26) Foothill of the Cabeça do Dragão mountain $\left(22^{\circ} 19^{\prime} \mathrm{S}, 42^{\circ} 43^{\prime} \mathrm{W}\right.$; 1,500-2,040 m), municipality of Nova Friburgo (high-montane forest, second growth, pasture and high grassland); 27) Headquarters of the Parque Estadual dos Três Picos (22 $24^{\prime} \mathrm{S}, 42^{\circ} 36^{\prime} \mathrm{W}$; 400-500 m), Boca do Mato in the municipality of Cachoeiras de Macacu (submontane forest and second growth); 28) Upper Rio Macacu ( $22^{\circ} 23^{\prime} \mathrm{S}, 4^{\circ} 35^{\prime} \mathrm{W}$; 500-600 m), Parque Estadual dos Três Picos, municipality of Cachoeiras de Macacu (submontane forest, second growth and swamps); 29) Middle Rio das Antas $\left(22^{\circ} 20^{\prime} \mathrm{S}, 42^{\circ} 48^{\prime} \mathrm{W}\right.$; 1,100-1,150 m), municipality of Teresópolis (montane forest and second growth); 30) Buraco do Ouro stream $\left(22^{\circ} 21^{\prime} \mathrm{S}, 42^{\circ} 49^{\prime} \mathrm{W} ; 1,200-1,250 \mathrm{~m}\right)$, municipality of Teresópolis (montane forest, second growth and swamps); 31) Serra da Caneca Fina ( $22^{\circ} 28^{\prime} \mathrm{S}, 42^{\circ} 56^{\prime} \mathrm{W}$; 200-600 $\mathrm{m})$, Parque Estadual dos Três Picos, municipality of Guapimirim (submontane forest and second growth); 32) Caminho do Ouro $\left(22^{\circ} 30^{\prime} \mathrm{S}, 42^{\circ} 56^{\prime} \mathrm{W} ; 250 \mathrm{~m}\right)$, municipality of Guapimirim (submontane forest and second growth); 33) Reserva Ecológica de Guapiaçu (REGUA) (22 $25^{\prime} \mathrm{S}, 42^{\circ} 44^{\prime} \mathrm{W}$; 100-1,300 m), municipality of Cachoeiras de Macacu (submontane forest, montane forest, second growth, wetland and swamps); 34) Centro Universitário Serra dos Órgãos (Unifeso) (22²3'S, 4257’W; 860$1,000 \mathrm{~m}$ ), municipality of Teresópolis (montane forest, second growth and urban area).

Our study is based on ornithological records obtained in surveys between 1991 and 2009 by walking along roads, trails, streets and in open areas, using the linear transect method (SutherLANd 1996). We have approximately 6,500 hours of field work during all seasons and months of the year. Birds were identified with binoculars ( $8 \times 40$ and $10 \times 50)$ and/or by their vocalizations. Eventually, birds were attracted using vocalization by "play-back" with a Sony TCM-5000 recorder and recorded with a directional microphone Sennheiser ME-66 in order to facilitate the visualization and identification of bird species. The altitudes were determined using an analogical al- timeter and a GPS (Garmin GPS 12). The taxonomy and systematics follow CBRO (2009), except for Chlorostilbon aureoventris (d'Orbigny \& Lafresnaye, 1838) (see MalletRoDRIGUEs 2005). We considered the threatened species (including also the probably threatened species) in the state of Rio de Janeiro (following Alves et al. 2000), and the endemic species of the Atlantic Forest (following Parker et al. 1996).

We determined differences in the proportion of endemic and threatened species in different altitudinal ranges using a chi-square test.

\section{RESULTS}

We recorded 426 bird species, belonging to 61 families (Appendix). The total number of species is approximately $90 \%$ of the birds known from the Serra dos Órgãos region (MaLletRodrigues et al. 2007).

The number of species revealed a considerable decline in species richness with increasing altitude, although a smaller number of species has been recorded at lower altitudes (below $300 \mathrm{~m}$ ). The largest number of bird species was found in the altitudinal range between 400 and 1,000 m (Fig. 2). Approximately $80 \%$ of the species recorded in the Serra dos Órgãos were found in this altitudinal range. A pronounced reduction in species richness was found from $1,100 \mathrm{~m}$ up, and only 52 species were recorded above 1,800 $\mathrm{m}$. Caprimulgus longirostris (Bonaparte, 1825) was the only species recorded exclusively in high grasslands above $2,000 \mathrm{~m}$.

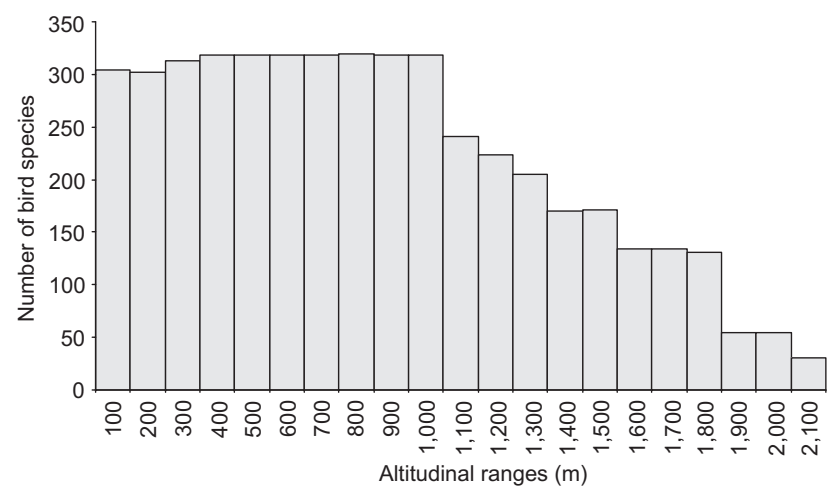

Figure 2. Species richness in each altitudinal range in the Serra dos Órgãos, southeastern Brazil.

All bird families found in the region were represented below $1,000 \mathrm{~m}$. The number of families also decreased with increasing altitude. Eight families (Anatidae, Phalacrocoracidae, Jacanidae, Tytonidae, Nyctibiidae, Galbulidae, Polioptilidae and Motacillidae) were recorded exclusively below 1,000 m.

We found 129 species endemic to the Atlantic forest. The proportion of endemic bird species varied with altitude. The 
proportion of endemic species in different altitudinal ranges was significantly different $\left(\chi^{2}=653.917, \mathrm{p}<0.01,20\right.$ d.f.). Although most endemic species were concentrated between 300 and 1,200 $\mathrm{m}$, endemism was more significant at higher altitudes (Fig. 3).

Forty seven species threatened in the state of Rio de Janeiro ( $11 \%$ of the species recorded in our study) were found in the Serra dos Órgãos. Threatened species were found predominantly below 1,200 m, while only one species, Tijuca condita Snow, 1980, was found exclusively in higher altitudes. However, the percentage of threatened species in different altitudinal ranges is not significantly different $\left(\chi^{2}=12.98, \mathrm{p}<\right.$ $0.01,20$ d.f.), with the proportion varying between $3.5 \%$ and $10.5 \%$ of threatened species among those recorded in each altitudinal range (Fig. 3).

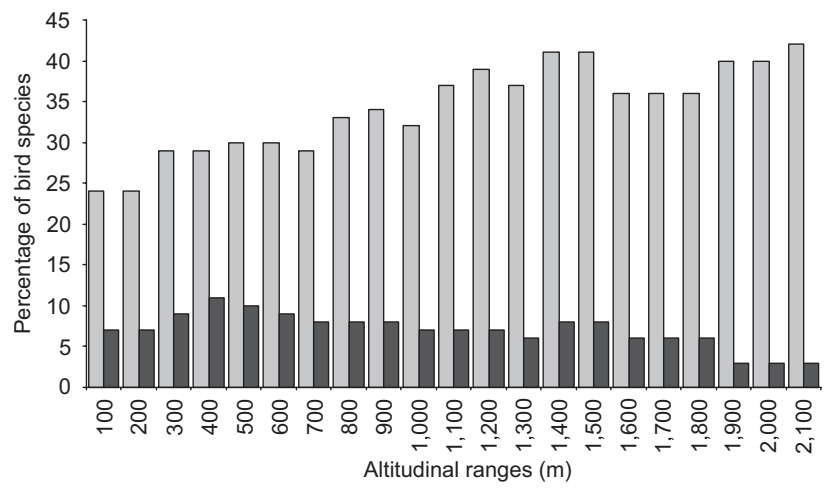

Figure 3. Percentage of bird species endemic to the Atlantic forest (gray bars) and threatened species in the state of Rio de Janeiro (dark bars) for each altitudinal range in the Serra dos Órgãos, southeastern Brazil.

Seventeen bird genera exhibited some elevational replacement of species in the Serra dos Órgãos (Tab. I). Among the non-passerines, three genera had a clear pattern of altitudinal replacement - Penelope Merrem, 1786, Phaethornis Swainson, 1827 and Piculus Spix, 1824. The two species of Penelope (Cracidae) found in the region - Penelope superciliaris Temminck, 1815 and Penelope obscura Temminck, 1815 - were not recorded sympatrically. Penelope superciliaris was rarer and not found above $400 \mathrm{~m}$, while $P$. obscura was recorded in localities above $800 \mathrm{~m}$, reaching up to around 2,000 $\mathrm{m}$.

Among the hummingbirds (Trochilidae), Phaethornis was represented by four forest species - Phaethornis squalidus (Temminck, 1822), Phaethornis ruber (Linnaeus, 1758), Phaethornis idaliae (Bourcier \& Mulsant, 1856) and Phaethornis eurynome (Lesson, 1832). The first three species occurred below $700 \mathrm{~m}$, while $P$. eurynome was found exclusively in montane forests. A fifth species, Phaethornis pretrei (Lesson \& Delattre, 1839), was not associated with forest formations.
Piculus flavigula (Boddaert, 1783) (Picidae) was found in the lower altitude forests below 1,000 m and Piculus aurulentus (Temminck, 1821) was found above $800 \mathrm{~m}$ to near 2,000 m. These two species were sympatric in one locality, between 800 and $980 \mathrm{~m}$.

Among the passerines, several genera had some altitudinal replacement between species in the Serra dos Órgãos. Two genera of the family Thamnophilidae (Thamnophilus Vieillot, 1816 and Drymophila Swainson, 1824) clearly showed a species replacement along altitudinal gradients. The species pairs Thamnophilus palliatus (Lichtenstein, 1823)/Thamnophilus ruficapillus (Vieillot, 1816) and Thamnophilus ambiguus Swainson, 1825/Thamnophilus caerulescens Vieillot, 1816 had one of their representatives at lower altitudes and the other in higher altitudes, without any recorded sympatry. Thamnophilus palliatus was always found below $600 \mathrm{~m}$ and T. ruficapillus from $850 \mathrm{~m}$ to near $2,100 \mathrm{~m}$, while $T$. ambiguus was restricted to altitudes below $400 \mathrm{~m}$ and T. caerulescens found from $800 \mathrm{~m}$ to near 2,000 m.

Six species of Drymophila were found in the region showing a pattern of gradual altitudinal substitution, with successive areas of sympatry between the species of neighboring altitudes. Drymophila squamata (Lichtenstein, 1823), the most common species in the foothills was found below $600 \mathrm{~m}$, where it is sympatric with Drymophila ferruginea (Temminck, 1822) which was found below $1,000 \mathrm{~m}$. Above $900 \mathrm{~m} \mathrm{D}$. ferruginea meets with D. ochropyga and Drymophila malura (Temminck, 1825), being replaced by its sister species, Drymophila rubricollis (Bertoni, 1901) at altitudes above 1,200 m. Drymophila ochropyga reaches up to about $1,300 \mathrm{~m}$, while $D$. malura and $D$. rubricollis to about $1,700 \mathrm{~m}$. The mountain top species is Drymophila genei (Filippi, 1847), recorded between 1,500 and 2,200 m.

Conopophaga melanops (Vieillot, 1818) and Conopophaga lineata (Wied, 1831) (Conopophagidae), although sympatric between 300 and $800 \mathrm{~m}$ (with syntopic records in four localities), are also altitudinally separated, with C. melanops restricted to the forests below $800 \mathrm{~m}$ and $C$. lineata found between 300 and near 2,000 $\mathrm{m}$.

The three species of Chamaeza Vigors, 1825 (Formicariidae) also showed a clear altitudinal replacement in the Serra dos Órgãos, with Chamaeza campanisona (Lichtenstein, 1823) present in the lower portion of the mountain, Chamaeza meruloides Vigors, 1825 in the intermediate altitudes (sympatric with $C$. campanisona above $800 \mathrm{~m}$ ) and Chamaeza ruficauda (Cabanis \& Heine, 1859) in higher elevations (sympatric with C. meruloides between 1,000 and 1,200 m).

Despite the richness of species in the region, the family Tyrannidae had few examples of altitudinal replacement. Hemitriccus orbitatus (Wied, 1831) was restricted to the forest below $1,000 \mathrm{~m}$. Above this altitude it is replaced by Hemtriccus diops (Temminck, 1822). These species were sympatric around $1,000 \mathrm{~m}$. A similar pattern of distribution was found in Myiobius barbatus (Gmelin, 1789) (below $900 \mathrm{~m}$ ) and Myiobius atricaudus 
Table I. Congeneric bird species with altitudinal replacement in the Serra dos Órgãos, southeastern Brazil.

\begin{tabular}{|c|c|c|}
\hline Lower montane species & Mid-montane species & Higher montane species \\
\hline Penelope superciliaris & Penelope obscura & Penelope obscura \\
\hline $\begin{array}{l}\text { Phaethornis squalidus, P. ruber and } \\
\text { P. idaliae }\end{array}$ & Phaethornis pretrei and P.eurynome & Phaethornis pretrei and P. eurynome \\
\hline Piculus flavigula & Piculus aurulentus & Piculus aurulentus \\
\hline Thamnophilus palliatus & Thamnophilus ruficapillus & Thamnophilus ruficapillus \\
\hline Thamnophilus ambiguus & Thamnophilus caerulescens & Thamnophilus caerulescens \\
\hline $\begin{array}{l}\text { Drymophila squamata, } D \text {. } \\
\text { ochropyga and } D \text {. ferruginea }\end{array}$ & $\begin{array}{l}\text { Drymophila ochropyga, } D \text {. ferruginea, } D \text {. } \\
\text { rubricollis and } D \text {. malura }\end{array}$ & $\begin{array}{l}\text { Drymophila ochropyga, D. ferruginea, D. rubricollis, } D \text {. } \\
\text { malura and D. genei }\end{array}$ \\
\hline Conopophaga melanops & Conopophaga lineata & Conopophaga lineata \\
\hline Chamaeza campanisona & $\begin{array}{l}\text { Chamaeza campanisona, C. meruloides and } \\
\text { C. ruficauda }\end{array}$ & C. ruficauda \\
\hline Hemitriccus orbitatus & Hemitriccus diops & Hemitriccus diops \\
\hline Myiobius barbatus & Myiobius atricaudus & Myiobius atricaudus \\
\hline Myiarchus tuberculifer & Myiarchus swainsoni & Myiarchus swainsoni \\
\hline $\begin{array}{l}\text { Phylloscartes paulista and } P \text {. } \\
\text { oustaleti }\end{array}$ & Phylloscartes ventralis and $P$. difficilis & Phylloscartes ventralis and $P$. difficilis \\
\hline \multirow[t]{2}{*}{ Carpornis melanocephala } & Carpornis cucullata & Carpornis cucullata \\
\hline & Tijuca atra & Tijuca condita \\
\hline Neopelma aurifrons & Neopelma chrysolophum & Neopelma chrysolophum \\
\hline Schiffornis turdina & Schiffornis virescens & Schiffornis virescens \\
\hline Hylophilus thoracicus & Hylophilus poiciloti and H. amaurocephalus & Hylophilus poicilotis \\
\hline Saltator maximus & Saltator similis & Saltator maxillosus \\
\hline $\begin{array}{l}\text { Tangara brasiliensis, } T \text {. seledon and } \\
\text { T. cyanocephala }\end{array}$ & $\begin{array}{l}\text { Tangara cyanoventris, } T \text {. cayana and } T \text {. } \\
\text { desmaresti }\end{array}$ & Tangara cayana and $T$. desmaresti \\
\hline
\end{tabular}

Lawrence, 1863 (above $900 \mathrm{~m}$ ), and between Myiarchus tuberculifer (d'Orbigny \& Lafresnaye, 1837) (below $700 \mathrm{~m}$ ) and Myiarchus swainsoni Cabanis \& Heine, 1859 (above $700 \mathrm{~m}$ ), although they were not observed to be sympatric in these two cases.

Among the four forest species of Phylloscartes Cabanis \& Heine, 1859 recorded in the region, Phylloscartes paulista Ihering \& Ihering, 1907 and Phylloscartes oustaleti (Sclater, 1887) were the forest species found at lower altitudes (up to 700-800 m), and the other two - Phylloscartes ventralis (Temminck, 1824) and Phylloscartes difficilis (Ihering \& Ihering, 1907) - were related to montane and high-montane forests.

Mionectes Cabanis, 1844, Tolmomyias Hellmayr, 1927 and Platyrinchus Desmarest, 1805 were also represented by pairs of forest species. Each genus was represented by one species found in lower elevation forests (up to $700 \mathrm{~m}$ ) - Mionectes oleagineus (Lichtenstein, 1823), Tolmomyias flaviventris (Wied, 1831) and Platyrinchus leucoryphus Wied, 1831 -, and the other species Mionectes rufiventris Cabanis, 1846, Tolmomyias sulphurescens (Spix, 1825), and Platyrinchus mystaceus Vieillot, 1818) - with a more extensive altitudinal distribution.
Among the cotingas, two cases of altitudinal substitution among pairs of similar species were recorded in the Serra dos Órgãos, Carpornis melanocephala (Wied, 1820)/Carpornis cucullata (Swainson, 1821) and Tijuca atra Ferrusac, 1829/Tijuca condita Snow, 1980.

Neopelma Sclater, 1861 (Pipridae) had another clear case of altitudinal replacement. Neopelma aurifrons (Wied, 1831) is restricted to lowland forest and Neopelma chrysolophum Pinto, 1944 is a montane species. A similar case occurs among two species of Schiffornis Bonaparte, 1854 (Tityridae).

Among the Oscine passerines, there are examples of altitudinal replacement in Hylophilus Temminck, 1822 (Vireonidae), Saltator Vieillot, 1816 (Thraupidae) and Tangara Brisson, 1760 (Thraupidae). Hylophilus thoracicus Temminck, 1822 was always recorded below $400 \mathrm{~m}$. Hylophilus poicilotis Temminck, 1822 was recorded between 700 and 1,600 m, and Hylophilus amaurocephalus (Nordmann, 1835) only between 850 and 1,000 m.

Saltator maximus (Statius Muller, 1776) was restricted to the lower altitude forests (below $500 \mathrm{~m}$ ), while Saltator maxillosus Cabanis, 1851 is a montane and high-montane forest species (between 900 and 2,100 m). Saltator similis Lafresnaye 
$\&$ d'Orbigny, 1837 had a wider distribution (between 300 and $2,000 \mathrm{~m}$ ) and is sympatric with $S$. maximus and S. maxillosus in part of its altitudinal range. In our study, Saltator fuliginosus (Daudin, 1800) was only found in forests below 1,000 m.

The six species of Tangara recorded in the Serra dos Órgãos fall into three basic groups of altitudinal distribution patterns. Tangara brasiliensis (Linnaeus, 1766), Tangara seledon (Statius Muller, 1776) and Tangara cyanocephala (Statius Muller, 1776) are species of lower elevations (below $600 \mathrm{~m}$ ). Tangara cyanoventris (Vieillot, 1819), an uncommon species in the region, was recorded in only two localities between 300 and 1,000 $\mathrm{m}$, while Tangara desmaresti (Vieillot, 1819) and Tangara cayana (Linnaeus, 1766) were found in a wide altitudinal range, but are more common above $1,000 \mathrm{~m}$.

\section{DISCUSSION}

The high number of bird species recorded during our study and the considerable amount of field work hours allow the recognition of altitudinal distribution patterns within this mountainous region in southeastern Brazil. The altitudinal distribution limits of many bird species reported here are in agreement with previous studies which focused on different bird community in the Serra dos Órgãos (DAVIS 1945, 1946, PARRINI et al. 2008) and with studies that reported bird records along the elevational gradient of this region (SCOTT \& BRooke 1985, Rajão \& Cerqueira 2006, Mallet-Rodrigues et al. 2007).

In our study, when plotting the number of species by altitudinal range, the decrease in species richness with increasing elevation is evident by the negative monotonic pattern in the shape of the curve, although the number of species found below $300 \mathrm{~m}$ was lower than at mid-elevations (300 to 1,200 $\mathrm{m})$. However, the mid-domain effect proposed by some authors (Rahbek 1995, Colwell \& Lees 2000, Colwell et al. 2004) with an unimodally shaped curve is not the natural pattern of bird altitudinal distribution for the region. The loss of species in the lower altitudes of the Serra dos Órgãos, as a result of anthropogenic pressure, may explain the lower bird richness found below $300 \mathrm{~m}$. The extreme fragmentation of lowland forests adjacent to the Serra dos Órgãos, the intensive human occupation of its foothills, combined with the insignificant protection of the slopes below $200 \mathrm{~m}$, probably contributes to the scarcity or absence of many bird species, such as some tinamous, large birds of prey, parrots and passerines. Changes in the altitudinal distribution of bird species as a result of human pressures have been previously proposed (SICK 1997, GoERCK 1999, Rajão \& Cerqueira 2006.

Although the loss of some species may be "impoverishing" the bird community of lower altitudes, we found that all the bird families in the Serra dos Órgãos are represented below $1,000 \mathrm{~m}$, with some of these families practically restricted to lower altitudes, as also recorded by other authors (Sсотт \& BRooke 1985, BuzzetTi 2000). Moreover, the scarcity of appro- priate habitats such as swamps and wetlands above $1,000 \mathrm{~m}$ may explain the absence of some families (i.e. Anatidae, Phalacrocoracidae and Jacanidae) at higher altitudes. Similarly, some species which depend on swamps and wetlands, such as Furnarius figulus (Lichtenstein, 1823), Certhiaxis cinnamomeus (Gmelin, 1788) (Furnariidae), and Fluvicola nengeta (Linnaeus, 1766) (Tyrannidae), have not been found in higher elevations, probably for the same reasons.

A large proportion of the variation in species richness with elevation has been explained by the extent of area of the altitudinal ranges (KATTAN \& FRANCO 2004). The area of the different elevational zones probably reflects the geometry of the mountain ranges. Lower altitudes on mountain ranges usually have larger areas than the higher altitudes. When controlling for area, the species richness remained constant along the altitudinal gradient and then decreased above 2,600 $\mathrm{m}$ in the Colombian Andes (Kattan \& Franco 2004). However, the factor area was not controlled here.

In our study, the altitudinal range dominated by high grasslands (above 2,000 m) had a less diverse avifauna, as has been found by other authors in the mountains of southeastern Brazil (Holt 1928, ScotT \& Brooke 1985). Only Caprimulgus longirostris was found above $2,000 \mathrm{~m}$ (although it is found at sea level in other regions of southeastern Brazil), while Oreophylax moreirae, endemic to the high grasslands from southeastern Brazil (Sick 1997), was recorded between 1,950 and 2,000 $\mathrm{m}$. The decline of species richness at high elevations may be related to higher extinction rates and lower resource levels (KatTAN \& Franco 2004).

The proportion of bird species endemic to the Atlantic forest had a clear relationship with increasing altitude. Nearly half of the birds recorded above $1,800 \mathrm{~m}$ were endemic species. ScotT \& BRooke (1985) also found an increase in the proportion of endemic species with increasing altitude in the Serra dos Órgãos, with approximately half of the species above 1,400 $\mathrm{m}$ being endemic. However, studying the distribution of birds along elevational gradients in another region of the Serra do Mar massif, GoеRCK (1999) found that most endemic and threatened species were restricted to the lower altitudes. This can be explained by the fact that many montane species living in the southeastern Brazil occur at sea level in the northern coast of the state of São Paulo and in the southern coast of the state of Rio de Janeiro, where Goerck (1999) conducted her study.

The lower altitudes have been identified as the most important areas of threatened bird species concentration in a mountain region (GoERcK 1999, BuzzetTi 2000). The destruction of forests in the lower altitudes (and adjacent lowlands) is the main cause of the scarcity of threatened species and the main threat to their survival. Thus, the effective protection of the lower altitude forests is now as important as the protection of the higher altitude forests. Our study has revealed that among the species recorded here, and considered threatened in the state of Rio de Janeiro (following Alves et al. 2000), the major- 
ity was found below $1,200 \mathrm{~m}$, even though there is not a significant relationship between altitude and proportion of threatened species found at each altitudinal range.

Our study presents some new altitudinal limits for certain species. Myrmotherula gularis (Spix, 1825) (Thamnophilidae) can be found at a lower altitude than the lower limit quoted by PARKer et al. (1996) (400 m) and Scott \& Brooke (1985) (300 m), but similar to that presented in BuzzetTi (2000) (between 10 and $30 \mathrm{~m}$ ). Another finding is the wider altitudinal sympatry of Leucopternis lacernulatus (Temminck, 1827) and L. polionotus (Kauppi, 1847) (Accipitridae) below 1,000 m. Leucopternis polionotus has been cited from Serra dos Órgãos in altitudes between 600 and 1,500 m (Sсотт \& BRooke 1985).

Although the mountain avifauna of eastern South America shows little species turnover along the altitudinal gradient when compared with the Andes (Willis \& SchuchmanN 1993), at least seventeen genera exhibited some replacement along altitudinal gradients in the Serra dos Órgãos. The altitudinal replacement between some of these species was previously reported by some authors (HoLt 1928, Willis 1988, 1992, Goerck 1999, Buzzetti 2000, Leme 2001, Rajão \& Cerqueira 2006) in other forested areas of southeastern Brazil.

Our study has not assessed the influence of certain ecological factors such as competition among species, the structure of vegetation and ecotones, or geophysical factors such as the extent of the study area. However, the existence of several species restricted to certain altitudinal ranges and the elevational replacement among related bird species found in this study suggest that several factors are acting in different ways on the distribution of the bird species along elevational gradients in the Serra dos Órgãos.

\section{ACKNOWLEDGEMENTS}

We are grateful to many people who helped us in obtaining the information presented in this study such as José Fernando Pacheco, Luiz Pedreira Gonzaga, Henrique Rajão, Fabio Olmos, Maria Luisa Marinho de Noronha, Flávio Medeiros de Britto, Flavio de Jesus and Adriano Luz Correa Pinto. Henrique Rajão kindly provided two important records (Macropsalis forcipata to 1,800 $\mathrm{m}$ and Megascops choliba above 2,000 m). Esther Parrini kindly revised the English manuscript. We also thank the staff of the Reserva Ecológica de Guapiaçu (REGUA) for their support and encouragement during the field work.

\section{LITERATURE CITED}

Alves, M.A.S.; J.F. Pacheco; L.A.P. Gonzaga; R.B. Cavalcanti; M.A. Raposo; C. Yamashita; N.C. Maciel \& M. Castanheira. 2000. Aves, p. 113-124. In: H.G. Bergallo; C.F.D. Rocha; M.A.S. Alves \& M.VAn Sluys (Orgs). A fauna ameaçada de extinção do Estado do Rio de Janeiro. Rio de Janeiro, EdUERJ, 166p. Amador, E.S. 1997. Baía de Guanabara e Ecossistemas Perifé- ricos: Homem e Natureza. Rio de Janeiro, Reproarte, 539p. BENCKE, G.A. \& A. KINDEL. 1999. Bird counts along an altitudinal gradient of Atlantic forest in northeastern Rio Grande do Sul, Brazil. Ararajuba 7 (2): 91-107.

BuzzetTI, D.R.C. 2000. Distribuição altitudinal de aves em Angra dos Reis e Parati, sul do Estado do Rio de Janeiro, Brasil, p. 131-148. In: M.A.S. Alves; J.M.C. Silva; M. Van Sluys; H.G. Bergalo \& C. F.D. Rocha (Orgs). A ornitologia no Brasil: Pesquisa atual e perspectivas. Rio de Janeiro, EdUERJ, 351p. CBRO. 2009. Listas das aves do Brasil. Comitê Brasileiro de Registros Ornitológicos. http://www.cbro.org.br [Accessed: 15.VIII.2009].

Colwell, R.K. \& D.C. Lees. 2000. The mid-domain effect: geometric constraints on the geography of species richness. Trends in Ecology and Evolution 15: 70-76.

Colwell, R.K.; C. Rahbek \& N.J. Gotelli. 2004. The mid-domain effect and species richness patterns: what have we learned so far? American Naturalist 163: E1E23. doi: 10.1086/ 382056.

DAvIs, D.E. 1945. The annual cycle of plants, mosquitoes, birds and mammals in two Brazilian forests. Ecological Monographs 15: 243-295.

DAvIS, D.E. 1946. A seasonal analysis of mixed flocks of birds in Brazil. Ecology 27: 168-181.

Goerck, J.M. 1999. Distribution of birds along an elevational gradient in the Atlantic Forest of Brazil: Implications for the conservation of endemic and endangered species. Bird Conservation International 9: 235-253.

Holt, E.G. 1928. An ornithological survey of Serra do Itatiaya, Brazil. Bulletin of the American Museum of Natural History 57: 251-326.

Kattan, G.H. \& P. Franco. 2004. Bird diversity along elevational gradients in the Andes of Colombia: Area and mass effects. Global Ecology and Biogeography 13: 451-458.

Leme, A. 2001. Foraging patterns and resource use in four sympatric species of antwrens. Journal of Field Ornithology 72 (2): 221-227.

LOISELle, B.A. \& J.G. BlAKE. 1991. Temporal variation in birds and fruits along an elevational gradient in Costa Rica. Ecology 72: 180-193.

Lomolino, M.V. 2001. Elevation gradients of species density: Historical and prospective views. Global Ecology and Biogeography 10: 3-13.

Mallet-Rodrigues, F. 2005. O beija-flor de Azara e seus enigmáticos derivados. Atualidades Ornitológicas 123: 3-4.

Mallet-Rodrigues, F.; R. Parrini \& J.F. Pacheco. 2007. Birds of the Serra dos Órgãos, State of Rio de Janeiro, Southeastern Brazil: A review. Revista Brasileira de Ornitologia 15 (1): 05-35.

NAVARro, A.G.S. 1992. Altitudinal distribution of birds in the Sierra Madre del Sur, Guerrero, Mexico. Condor 94: 29-39.

Noon, B.R. 1981. The distribution of an avian guild along a temperate elevational gradient: The importance and expression of competition. Ecology 51: 105-124. 
Parker, T.A.; D.F. Stotz \& J.W. Fitzpatrick. 1996. Ecological and distributional databases, p. 113-436. In: D.F. Stotz; J.W. Fitzpatrick; T.A. Parker \& D.K. Moskovits. Neotropical Birds. Ecology and Conservation. Chicago, University of Chicago Press, 502p.

Parrini, R.; J.F. Pacheco \& L. Haefeli. 2008. Observação de aves se alimentando dos frutos de Miconia sellowiana (Melastomataceae) na Floresta Atlântica Alto-Montana do Parque Nacional da Serra dos Órgãos e do Parque Nacional do Itatiaia, região Sudeste do Brasil. Atualidades Ornitológicas 146: 4-7.

RADAMBRASIL. 1983. Levantamento de recursos naturais: folhas SF23/24 Rio de Janeiro/Vitória. Geologia, geomorfologia, pedologia, vegetação e uso potencial da terra. Rio de Janeiro, Projeto RADAMBRASIL,780p.

RAнвек, C. 1995. The elevational gradient of species richness: A uniform pattern Ecography 18: 200-205.

Rajão, H. \& R. Cerqueira. 2006. Distribuição altitudinal e simpatria das aves do gênero Drymophila Swainson (Passeriformes, Thamnophilidae) na Mata Atlântica. Revista Brasileira de Zoologia 23 (3): 597-607.

ScotT, D.A. \& M.L. Brooke. 1985. The endangered avifauna of Southeastern Brazil: A report on the BOU/WWF expeditions of $1980 / 81$ and $1981 / 82$, p. $115-139$. In: A.W. Diamond \&
T.E. Lovejoy (Eds). Conservation of Tropical Forest Birds. Cambridge, ICBP, Technical Publication \#4, 324p.

Sick, H. 1997. Ornitologia brasileira. Rio de Janeiro, Editora Nova Fronteira, 861p.

Sutherland, W.J. 1996. Ecological census technique: a handbook. Cambridge, Cambridge University Press, 448p.

Terborgh, J. 1971. Distribution on environmental gradients: Theory and a preliminary interpretation of distributional patterns in the avifauna of the Cordillera Vilcabamba, Peru. Ecology 52: 23-40.

Terborgh, J. 1977. Bird species diversity on an Andean elevation gradient. Ecology 58: 1007-1019.

Veloso, H.P.; A.L.R. Rangel Filho \& J.C.A. Lima. 1991. Classificação da vegetação brasileira, adaptada a um sistema universal. Rio de Janeiro, IBGE, Departamento de Recursos Naturais e Estudos Ambientais, 123p.

WiLlis, E.O. 1988. Drymophila rubricollis (Bertoni, 1901) is a valid species (Aves, Formicariidae). Revista Brasileira de Biologia 48: 431-438.

Willis, E.O. 1992. Three Chamaeza Antthrushes in eastern Brazil (Formicariidae). Condor 94: 110-116.

Willis, E.O. \& K.L. Schuchmann. 1993. Comparison of cloudforest avifaunas in southeastern Brazil and western Colombia. Ornitologia Neotropical 4: 55-63.

Appendix. Bird species recorded in the Serra dos Órgãos region in their respective altitudinal ranges. (E) Species endemic to the Atlantic forest (PARKer et al. 1996); (A) Species threatened in the state of Rio de Janeiro (Alves et al. 2000); (P) Presumed occurrence.

\begin{tabular}{|c|c|c|}
\hline Species & Altitudinal range & Localities \\
\hline \multicolumn{3}{|l|}{ Tinamidae } \\
\hline Tinamus solitarius (Vieillot, 1819) E, A & 300 to $900 \mathrm{~m}$ & 28,33 \\
\hline Crypturellus soui (Hermann, 1783) & Below $300 \mathrm{~m}$ & 1 \\
\hline Crypturellus obsoletus (Temminck, 1815) & To $2,100 \mathrm{~m}$ & $\begin{array}{l}1,2,3,6,10,11,12,13,14,16,17,21,24,33, \\
34\end{array}$ \\
\hline Crypturellus tataupa (Temminck, 1815) & To $1,200 \mathrm{~m}$ & $1,3,5,6,11,16,21,31,32,33,34$ \\
\hline \multicolumn{3}{|l|}{ Anatidae } \\
\hline Dendrocygna viduata (Linnaeus, 1766) & Below $300 \mathrm{~m}$ & 3,5 \\
\hline Amazonetta brasiliensis (Gmelin, 1789) & To $1,000 \mathrm{~m}$ & 1,18 \\
\hline \multicolumn{3}{|l|}{ Cracidae } \\
\hline Penelope superciliaris Temminck, 1815 & Below $400 \mathrm{~m}$ & $3,5,33$ \\
\hline Penelope obscura Temminck, 1815 & 800 to $2,000 \mathrm{~m}$ & $12,13,14,17,24,33,34$ \\
\hline \multicolumn{3}{|l|}{ Odontophoridae } \\
\hline Odontophorus capueira (Spix, 1825) E, A & 300 to $1,500 \mathrm{~m}$ & $6,11,12,13,15,17,27,33$ \\
\hline \multicolumn{3}{|l|}{ Podicipedidae } \\
\hline Tachybaptus dominicus (Linnaeus, 1766) & To $1,000 \mathrm{~m}$ & $1,9,12$ \\
\hline \multicolumn{3}{|l|}{ Phalacrocoracidae } \\
\hline Phalacrocorax brasilianus (Gmelin, 1789) & To $900 \mathrm{~m}$ & $5,6,11$ \\
\hline \multicolumn{3}{|l|}{ Ardeidae } \\
\hline Tigrisoma lineatum (Boddaert, 1783) & Below $300 \mathrm{~m}$ & 5 \\
\hline
\end{tabular}


Appendix. Continued

\begin{tabular}{|c|c|c|}
\hline Species & Altitudinal range & Localities \\
\hline Nycticorax nycticorax (Linnaeus, 1758) & To $1,000 \mathrm{~m}$ & $3,5,18,19$ \\
\hline Butorides striata (Linnaeus, 1758) & To $1,000 \mathrm{~m}$ & $2,11,12,18,19$ \\
\hline Bubulcus ibis (Linnaeus, 1758) & Below 300 m & 2 \\
\hline Ardea alba Linnaeus, 1758 & Below 300 m & 1 \\
\hline Syrigma sibilatrix (Temminck, 1824) & Below 300 m & 2 \\
\hline Pilherodius pileatus (Boddaert, 1783) A & Below $300 \mathrm{~m}$ & 1 \\
\hline Egretta thula (Molina, 1782) & To $1,000 \mathrm{~m}$ & 5,18 \\
\hline \multicolumn{3}{|l|}{ Threskiornithidae } \\
\hline Theristicus caudatus (Boddaert, 1783) & To $1,000 \mathrm{~m}$ & 1,18 \\
\hline \multicolumn{3}{|l|}{ Cathartidae } \\
\hline Cathartes aura (Linnaeus, 1758) & To $2,100 \mathrm{~m}$ & $1,2,3,11,16,17,23,33$ \\
\hline Cathartes burrovianus Cassin, 1845 & To $1,100 \mathrm{~m}$ & $2,20,29$ \\
\hline Coragyps atratus (Bechstein, 1793) & To $2,100 \mathrm{~m}$ & $\begin{array}{l}2,3,6,7,9,10,11,13,14,16,17,19,20,23 \\
29,30,31,33,34\end{array}$ \\
\hline \multicolumn{3}{|l|}{ Accipitridae } \\
\hline Leptodon cayanensis (Latham, 1790) & To $1,100 \mathrm{~m}$ & $3,11,13,19,33,34$ \\
\hline Chondrohierax uncinatus (Temminck, 1822) & One record (ca. 1,000 m) & 16 \\
\hline Elanus leucurus (Vieillot, 1818) & One record (ca. 1,000 m) & 18 \\
\hline Harpagus diodon (Temminck, 1823) & To $1,100 \mathrm{~m}$ & $6,7,8,10,11,14,33$ \\
\hline Accipiter striatus Vieillot, 1808 & 1,000 to $1,900 \mathrm{~m}$ & $14,16,17,24$ \\
\hline Accipiter bicolor (Vieillot, 1817) A & To $600 \mathrm{~m}$ & 33 \\
\hline Geranospiza caerulescens (Vieillot, 1817) & To $1,000 \mathrm{~m}$ & 16,33 \\
\hline Leucopternis lacernulatus (Temminck, 1827) E, A & To $1,000 \mathrm{~m}$ & $2,3,6,7,11,33$ \\
\hline Leucopternis polionotus (Kaup, 1847) E, A & To $1,500 \mathrm{~m}$ & $6,8,10,13,17,25,33$ \\
\hline Heterospizias meridionalis (Latham, 1790) & To $1,300 \mathrm{~m}$ & $2,5,9,16,20,24,31,33,34$ \\
\hline Harpyhaliaetus coronatus (Vieillot, 1817) A & 300 to $1,800 \mathrm{~m}$ & $9,17,33$ \\
\hline Percnohierax leucorrhous (Quoy \& Gaimard, 1824) & 300 to $1,800 \mathrm{~m}$ & $11,16,17,33$ \\
\hline Rupornis magnirostris (Gmelin, 1788) & To $2,000 \mathrm{~m}$ & $\begin{array}{l}1,2,6,7,10,11,12,13,16,17,19,22,21,22 \\
23,24,25,27,31,33,34\end{array}$ \\
\hline Buteo albicaudatus Vieillot, 1816 & To $2,100 \mathrm{~m}$ & $9,16,17,18,19,20,26,33,34$ \\
\hline Buteo brachyurus Vieillot, 1816 & To $2,100 \mathrm{~m}$ & $5,11,12,13,17,19,34$ \\
\hline Buteo albonotatus Kaup, 1847 & Few records at $900 \mathrm{~m}$ & 11 \\
\hline Spizaetus tyrannus (Wied, 1820) A & To $1,800 \mathrm{~m}$ & $2,3,6,10,11,13,14,16,17,33,34$ \\
\hline Spizaetus melanoleucus Vieillot, 1816 A & To $1,000 \mathrm{~m}$ & $6,7,33$ \\
\hline \multicolumn{3}{|l|}{ Falconidae } \\
\hline Caracara plancus (Miller, 1777) & To $2,100 \mathrm{~m}$ & $1,3,5,6,9,11,12,14,16,26,33,34$ \\
\hline Milvago chimachima (Vieillot, 1816) & To $1,800 \mathrm{~m}$ & $1,2,5,6,9,11,16,17,20,21,23,24,33,34$ \\
\hline Herpetotheres cachinnans (Linnaeus, 1758) & To $1,000 \mathrm{~m}$ & $1,6,9,11,33$ \\
\hline Micrastur ruficollis (Vieillot, 1817) & 300 to $1,800 \mathrm{~m}$ & $3,6,10,11,12,13,14,17,23,27,33$ \\
\hline Micrastur semitorquatus (Vieillot, 1817) & To $600 \mathrm{~m}$ & $1,7,33$ \\
\hline Falco sparverius Linnaeus, 1758 & To $1,800 \mathrm{~m}$ & $2,9,16,18,26,31,33$ \\
\hline Falco rufigularis Daudin, 1800 & To $900 \mathrm{~m}$ & 19,33 \\
\hline Falco femoralis Temminck, 1822 & To $1,800 \mathrm{~m}$ & $1,5,9,17,20,33,34$ \\
\hline
\end{tabular}


Appendix 1. Continued.

\begin{tabular}{|c|c|c|}
\hline Species & Altitudinal range & Localities \\
\hline \multicolumn{3}{|l|}{ Rallidae } \\
\hline Aramides saracura (Spix, 1825) E & To $1,500 \mathrm{~m}$ & $1,3,11,12,13,17,19,22,24,33$ \\
\hline Laterallus melanophaius (Vieillot, 1819) & Below $300 \mathrm{~m}$ & 31 \\
\hline Porzana albicollis (Vieillot, 1819) & To $1,000 \mathrm{~m}$ & $2,5,20$ \\
\hline Pardirallus nigricans (Vieillot, 1819) & To $1,200 \mathrm{~m}$ & $2,4,5,9,11,13,20,24$ \\
\hline Gallinula chloropus (Linnaeus, 1758) & To $900 \mathrm{~m}$ & 5,11 \\
\hline \multicolumn{3}{|l|}{ Cariamidae } \\
\hline Cariama cristata (Linnaeus, 1766) & 600 to $1,500 \mathrm{~m}$ & $9,11,25,29,34$ \\
\hline \multicolumn{3}{|l|}{ Charadriidae } \\
\hline Vanellus chilensis (Molina, 1782) & To $1,800 \mathrm{~m}$ & $2,9,11,16,19,20,22,23,24,34$ \\
\hline \multicolumn{3}{|l|}{ Scolopacidae } \\
\hline Tringa flavipes (Gmelin, 1789) & One record (ca. 1,000 m) & 18 \\
\hline Calidris fuscicollis (Vieillot, 1819) & One record (ca. 1,000 m) & 18 \\
\hline \multicolumn{3}{|l|}{ Jacanidae } \\
\hline Jacana jacana (Linnaeus, 1766) & Below $300 \mathrm{~m}$ & 2 \\
\hline \multicolumn{3}{|l|}{ Columbidae } \\
\hline Columbina minuta (Linnaeus, 1766) & Below 300 m & 1 \\
\hline Columbina talpacoti (Temminck, 1811) & To $1,500 \mathrm{~m}$ & $\begin{array}{l}1,2,3,4,5,7,9,11,12,13,16,19,20,25 \\
27,33,34\end{array}$ \\
\hline Claravis pretiosa (Ferrari-Perez, 1886) & To $1,200 \mathrm{~m}$ & $5,11,14$ \\
\hline Columba livia Gmelin, 1789 & To $1,200 \mathrm{~m}$ & $3,5,11,16,19,24,34$ \\
\hline Patagioenas picazuro (Temminck, 1813) & To $1,200 \mathrm{~m}$ & $2,5,7,9,11,13,19,21,29,33,34$ \\
\hline Patagioenas cayennensis (Bonnaterre, 1792) & To $1,800 \mathrm{~m}$ & $16,17,20,33$ \\
\hline Patagioenas plumbea (Vieillot, 1818) & 300 to $1,800 \mathrm{~m}$ & $3,10,11,12,13,14,17,33$ \\
\hline Leptotila verreauxi Bonaparte, 1855 & To $1,000 \mathrm{~m}$ & $1,3,11,15,20,31,32,33,34$ \\
\hline Leptotila rufaxilla (Richard \& Bernard, 1792) & To $1,500 \mathrm{~m}$ & $3,11,16,17,21,22,24,25,31,33,34$ \\
\hline Geotrygon montana (Linnaeus, 1758) & To $1,800 \mathrm{~m}$ & $1,3,6,10,11,12,13,17,23,31,33$ \\
\hline \multicolumn{3}{|l|}{ Psittacidae } \\
\hline Primolius maracana (Vieillot, 1816) & To $1,200 \mathrm{~m}$ & $6,9,10,11,16,19,33,34$ \\
\hline Aratinga leucophthalma (Statius Muller, 1776) & To $1,800 \mathrm{~m}$ & $\begin{array}{l}6,9,10,11,16,17,18,19,23,26,29,30,33 \\
34\end{array}$ \\
\hline Pyrrhura frontalis (Vieillot, 1817) E & To $2,000 \mathrm{~m}$ & $\begin{array}{l}2,3,4,5,6,7,10,11,12,13,17,19,21,22 \\
24,27,33,34\end{array}$ \\
\hline Forpus xanthopterygius (Spix, 1824) & To $1,000 \mathrm{~m}$ & $\begin{array}{l}2,3,5,6,7,9,11,13,15,16,19,21,27,33 \\
34\end{array}$ \\
\hline Brotogeris tirica (Gmelin, 1788) E & To $1,200 \mathrm{~m}$ & $\begin{array}{l}1,2,5,6,7,10,11,12,13,14,21,27,28,33 \\
34\end{array}$ \\
\hline Touit melanonotus (Wied, 1820) E, A & 300 to $1,200 \mathrm{~m}$ & $3,10,11,14,15,19,33$ \\
\hline Touit surdus (Kuhl, 1820) E, A & To $1,000 \mathrm{~m}$ & $3,7,14,16,33$ \\
\hline Pionopsitta pileata (Scopoli, 1769) E, A & 300 to $1,500 \mathrm{~m}$ & $6,10,11,12,13,14,17,33$ \\
\hline Pionus maximiliani (Kuhl, 1820) & To $1,800 \mathrm{~m}$ & $\begin{array}{l}1,2,4,6,7,10,11,12,13,14,16,17,19,21 \\
22,23,24,27,28,29,30,31,32,33,34\end{array}$ \\
\hline Triclaria malachitacea (Spix, 1824) E, A & 300 to $1,200 \mathrm{~m}$ & 28,33 \\
\hline
\end{tabular}


Appendix 1. Continued.

\begin{tabular}{|c|c|c|}
\hline Species & Altitudinal range & Localities \\
\hline \multicolumn{3}{|l|}{ Cuculidae } \\
\hline Piaya cayana (Linnaeus, 1766) & To $2,000 \mathrm{~m}$ & $\begin{array}{l}1,2,3,4,5,7,10,11,13,14,16,17,20,24,26 \\
28,31,32,33,34\end{array}$ \\
\hline Coccyzus americanus (Linnaeus, 1758) & Below $300 \mathrm{~m}$ & 2 \\
\hline Coccyzus euleri Cabanis, 1783 & To $900 \mathrm{~m}$ & 2,12 \\
\hline Crotophaga ani Linnaeus, 1758 & To $1,300 \mathrm{~m}$ & $2,3,4,6,9,11,13,16,18,21,24,33,34$ \\
\hline Guira guira (Gmelin, 1788) & To $1,300 \mathrm{~m}$ & $2,3,5,6,7,9,10,20,21,24,29,30,33,34$ \\
\hline Tapera naevia (Linnaeus, 1766) & To $1,200 \mathrm{~m}$ & $11,13,20,34$ \\
\hline \multicolumn{3}{|l|}{ Tytonidae } \\
\hline Tyto alba (Scopoli, 1769) & Below $300 \mathrm{~m}$ & 1,5 \\
\hline \multicolumn{3}{|l|}{ Strigidae } \\
\hline Megascops choliba (Vieillot, 1817) & To $2,000 \mathrm{~m}$ & $11,17,19,24,31,32,34$ \\
\hline Pulsatrix koeniswaldiana (Bertoni \& Bertoni, 1901) E & To $1,500 \mathrm{~m}$ & $2,3,10,13,17,21,27,28,31,33$ \\
\hline Strix hylophila Temminck, $1825 \mathrm{E}$ & 600 to $1,800 \mathrm{~m}$ & 12,17 \\
\hline Strix virgata (Cassin, 1849) & Below $300 \mathrm{~m}$ & 5 \\
\hline Strix huhula Daudin, $1800 \mathrm{~A}$ & 300 to $600 \mathrm{~m}$ & 27,33 \\
\hline Glaucidium minutissimum (Wied, 1830) E & 300 to $900 \mathrm{~m}$ & 6,33 \\
\hline Glaucidium brasilianum (Gmelin, 1788) & To $1,800 \mathrm{~m}$ & $3,17,32,33$ \\
\hline Athene cunicularia (Molina, 1782) & To $1,500 \mathrm{~m}$ & $2,9,11,24,25,34$ \\
\hline Rhinoptynx clamator (Vieillot, 1808) & To $900 \mathrm{~m}$ & $5,11,13,19$ \\
\hline \multicolumn{3}{|l|}{ Nyctibiidae } \\
\hline Nyctibius aethereus (Wied, 1820) A & One record (ca. $400 \mathrm{~m}$ ) & 33 \\
\hline Nyctibius griseus (Gmelin, 1789) & To $900 \mathrm{~m}$ & $6,11,31,32,33$ \\
\hline \multicolumn{3}{|l|}{ Caprimulgidae } \\
\hline Lurocalis semitorquatus (Gmelin, 1789) & To $1,000 \mathrm{~m}$ & $7,11,13,33$ \\
\hline Nyctidromus albicollis (Gmelin, 1789) & To $1,100 \mathrm{~m}$ & $3,9,11,24,32,33$ \\
\hline Nyctiphrynus ocellatus (Tschudi, 1844) & 600 to $1,200 \mathrm{~m}$ & 11,16 \\
\hline Caprimulgus longirostris Bonaparte, 1825 & Above $2,000 \mathrm{~m}$ & 17 \\
\hline Macropsalis forcipata (Nitzsch, 1840) E & 800 to $1,800 \mathrm{~m}$ & 11,17 \\
\hline \multicolumn{3}{|l|}{ Apodidae } \\
\hline Streptoprocne zonaris (Shaw, 1796) & To $1,800 \mathrm{~m}$ & $2,3,6,7,9,10,11,13,17,19,22,31,33,34$ \\
\hline Streptoprocne biscutata (Sclater, 1866) & To $2,100 \mathrm{~m}$ & $2,3,6,16,17,18,19,33$ \\
\hline Chaetura cinereiventris Sclater, 1862 & To $1,100 \mathrm{~m}$ & $1,2,6,7,8,12,13,21,24,27,33$ \\
\hline Chaetura meridionalis Hellmayr, 1907 & To $1,800 \mathrm{~m}$ & $1,2,3,6,11,12,13,17,19,22,33,34$ \\
\hline Panyptila cayennensis (Gmelin, 1789) & To $600 \mathrm{~m}$ & $3,6,33$ \\
\hline \multicolumn{3}{|l|}{ Trochilidae } \\
\hline Ramphodon naevius (Dumont, 1818) E, A & To $900 \mathrm{~m}$ & $1,2,3,4,6,7,12,21,27,31,33$ \\
\hline Glaucis hirsutus (Gmelin, 1788) & To $600 \mathrm{~m}$ & $1,2,3,33$ \\
\hline Phaethornis squalidus (Temminck, 1822) E & 300 to $600 \mathrm{~m}$ & 6,33 \\
\hline Phaetornis idaliae (Bourcier \& Mulsant, 1856) E, A & Below $300 \mathrm{~m}$ & 33 \\
\hline Phaethornis ruber (Linnaeus, 1758) & To $700 \mathrm{~m}$ & $1,3,6,28,33$ \\
\hline Phaethornis pretrei (Lesson \& Delattre, 1839) & 800 to $1,800 \mathrm{~m}$ & $9,12,19,20,23,33,34$ \\
\hline Phaethornis eurynome (Lesson, 1832) E & 400 to $2,100 \mathrm{~m}$ & $10,11,12,13,14,16,17,19,22,23,24,27,33,34$ \\
\hline Eupetomena macroura (Gmelin, 1788) & To $1,300 \mathrm{~m}$ & $1,2,6,7,8,10,11,16,19,20,25,33,34$ \\
\hline
\end{tabular}


Appendix. Continued.

\begin{tabular}{|c|c|c|}
\hline Species & Altitudinal range & Localities \\
\hline Aphantochroa cirrochloris (Vieillot, 1818) E & To $1,100 \mathrm{~m}$ & $4,5,6,8,15,19,27,28,33,34$ \\
\hline Florisuga fusca (Vieillot, 1817) E & To $1,500 \mathrm{~m}$ & $2,3,6,7,9,10,11,12,16,17,19,22,33,34$ \\
\hline Colibri serrirostris (Vieillot, 1816) & To $2,100 \mathrm{~m}$ & $16,17,20,33,34$ \\
\hline Stephanoxis lalandi (Vieillot, 1818) E & 600 to $2,100 \mathrm{~m}$ & $11,13,14,16,17,23$ \\
\hline Lophornis magnificus (Vieillot, 1817) & To $600 \mathrm{~m}$ & $3,6,33$ \\
\hline Chlorostilbon aureoventris (d’Orbigny \& Lafresnaye, 1838) & 300 to $1,200 \mathrm{~m}$ & $11,16,19,20,24,29,33,34$ \\
\hline Thalurania glaucopis (Gmelin, 1788) E & To $1,200 \mathrm{~m}$ & $\begin{array}{l}1,2,4,6,7,8,9,10,11,13,16,17,19,20 \\
27,31,33,34\end{array}$ \\
\hline Hylocharis cyanus (Vieillot, 1818) & Below $400 \mathrm{~m}$ & $1,3,33$ \\
\hline Leucochloris albicollis (Vieillot, 1818) E & 300 to $2,100 \mathrm{~m}$ & $6,10,11,12,14,16,17,19,23,26,33,34$ \\
\hline Amazilia versicolor (Vieillot, 1818) & To $1,200 \mathrm{~m}$ & $5,6,7,11,16,17,33,34$ \\
\hline Amazilia lactea (Lesson, 1832) & To $1,200 \mathrm{~m}$ & $11,12,16,20,33,34$ \\
\hline Clytolaema rubricauda (Boddaert, 1783) E & To $2,100 \mathrm{~m}$ & $6,10,11,12,13,14,16,17,23,24,33,34$ \\
\hline Calliphlox amethystina (Boddaert, 1783) & To $1,000 \mathrm{~m}$ & $10,11,16,19,33,34$ \\
\hline \multicolumn{3}{|l|}{ Trogonidae } \\
\hline Trogon viridis Linnaeus, 1766 & To $600 \mathrm{~m}$ & $1,6,27,33$ \\
\hline Trogon surrucura Vieillot, 1817 E & To $1,800 \mathrm{~m}$ & $6,10,11,12,13,14,17,33,34$ \\
\hline Trogon rufus Gmelin, 1788 & To $1,800 \mathrm{~m}$ & $1,6,7,8,10,12,13,14,17,21,22,23,31,33$ \\
\hline \multicolumn{3}{|l|}{ Alcedinidae } \\
\hline Megaceryle torquatus (Linnaeus, 1766) & To $1,000 \mathrm{~m}$ & $2,3,9,11,13,18,19,33,34$ \\
\hline Chloroceryle amazona (Latham, 1790) & To $1,000 \mathrm{~m}$ & $5,9,19$ \\
\hline Chloroceryle americana (Gmelin, 1788) & To $1,000 \mathrm{~m}$ & $2,5,13,19$ \\
\hline \multicolumn{3}{|l|}{ Momotidae } \\
\hline Baryphthengus ruficapillus (Vieillot, 1818) E & To $1,500 \mathrm{~m}$ & $1,2,6,7,8,11,12,14,17,27,32,33$ \\
\hline \multicolumn{3}{|l|}{ Galbulidae } \\
\hline Galbula ruficauda Cuvier, 1816 & To $600 \mathrm{~m}$ & $1,2,4,8,33$ \\
\hline \multicolumn{3}{|l|}{ Bucconidae } \\
\hline Notharchus swainsoni (Gray, 1846) E, A & 300 to $600 \mathrm{~m}$ & 8,33 \\
\hline Nystalus chacuru (Vieillot, 1816) & To $1,800 \mathrm{~m}$ & $1,9,11,12,17,20,24,33,34$ \\
\hline Malacoptila striata (Spix, 1824) E & To $1,200 \mathrm{~m}$ & $2,6,7,8,11,13,27,33,34$ \\
\hline \multicolumn{3}{|l|}{ Ramphastidae } \\
\hline Ramphastos vitellinus Lichtenstein, 1823 & To $1,000 \mathrm{~m}$ & $1,2,6,11,14,15,21,27,28,31,32,33$ \\
\hline Ramphastos dicolorus Linnaeus, $1766 \mathrm{E}$ & 300 to $900 \mathrm{~m}$ & 33 \\
\hline Selenidera maculirostris (Lichtenstein, 1823) E & To $1,800 \mathrm{~m}$ & $2,6,7,10,11,12,17,24,27,28,31,33$ \\
\hline Pteroglossus bailloni (Vieillot, 1819) E & 300 to $1,800 \mathrm{~m}$ & $6,10,14,17,27,33,34$ \\
\hline \multicolumn{3}{|l|}{ Picidae } \\
\hline Picumnus cirratus Temminck, 1825 & To $1,500 \mathrm{~m}$ & $\begin{array}{l}1,2,4,6,7,9,12,13,16,17,19,20,21 \\
27,31,33,34\end{array}$ \\
\hline Melanerpes candidus (Otto, 1796) & To $1,200 \mathrm{~m}$ & $2,4,9,11,19,20,29,30,33,34$ \\
\hline Melanerpes flavifrons (Vieillot, 1818) E & To $1,100 \mathrm{~m}$ & $2,6,8,10,12,33$ \\
\hline Veniliornis maculifrons (Spix, 1824) E & To $1,800 \mathrm{~m}$ & $\begin{array}{l}2,6,7,8,11,12,13,14,16,17,24,29,30 \\
31,33,34\end{array}$ \\
\hline Piculus flavigula (Boddaert, 1783) & To $1,000 \mathrm{~m}$ & $1,2,3,6,7,8,12,31,33$ \\
\hline Piculus aurulentus (Temminck, 1821) E & 800 to $1,800 \mathrm{~m}$ & $10,11,12,13,16,17,24,33,34$ \\
\hline
\end{tabular}


Appendix. Continued.

\begin{tabular}{|c|c|c|}
\hline Species & Altitudinal range & Localities \\
\hline Colaptes melanochloros (Gmelin, 1788) & To $1,200 \mathrm{~m}$ & $4,5,6,7,10,11,14,16,33,34$ \\
\hline Colaptes campestris (Vieillot, 1818) & To $1,800 \mathrm{~m}$ & $2,9,12,16,20,21,23,24,33,34$ \\
\hline Celeus flavescens (Gmelin, 1788) & To $1,500 \mathrm{~m}$ & $1,2,4,6,7,8,11,12,14,15,17,28,31,33,34$ \\
\hline Dryocopus lineatus (Linnaeus, 1766) & 600 to $1,200 \mathrm{~m}$ & 16,33 \\
\hline Campephilus robustus (Lichtenstein, 1818) E, A & One record to $1,000 \mathrm{~m}$ & 10 \\
\hline \multicolumn{3}{|l|}{ Thamnophilidae } \\
\hline Hypoedaleus guttatus (Vieillot, 1816) E & To $900 \mathrm{~m}$ & $1,2,6,12,21,27,31,33$ \\
\hline Batara cinerea Vieillot, 1819 & To $2,000 \mathrm{~m}$ & $6,10,11,12,13,14,17,24,26,33,34$ \\
\hline Mackenziaena leachii (Such, 1825) E & To $2,000 \mathrm{~m}$ & $11,12,17,20,23,26$ \\
\hline Mackenziaena severa (Lichtenstein, 1823) E & To $1,500 \mathrm{~m}$ & $8,10,11,12,13,14,16,17,25,31,33,34$ \\
\hline Biatas nigropectus (Lafresnaye, 1850) E, A & 600 to $1,500 \mathrm{~m}$ & $10,11,14,17,33$ \\
\hline Thamnophilus ruficapillus Vieillot, 1816 & 850 to $2,100 \mathrm{~m}$ & $9,11,16,17,20,23,25,26,34$ \\
\hline Thamnophilus palliatus (Lichtenstein, 1823) & To $600 \mathrm{~m}$ & $1,5,8,31,33$ \\
\hline Thamnophilus ambiguus Swainson, $1825 \mathrm{E}$ & To $400 \mathrm{~m}$ & $1,4,8,32$ \\
\hline Thamnophilus caerulescens Vieillot, 1816 & 800 to $2,000 \mathrm{~m}$ & $\begin{array}{l}9,10,11,12,14,16,17,19,23,24,29,30,33 \\
34\end{array}$ \\
\hline Dysithamnus stictothorax (Temminck, 1823) E & To $1,300 \mathrm{~m}$ & $2,3,6,7,10,11,12,17,21,27,33$ \\
\hline Dysithamnus mentalis (Temminck, 1823) & To $1,500 \mathrm{~m}$ & $3,6,8,11,12,17,22,24,27,33,34$ \\
\hline Dysithamnus xanthopterus Burmeister, $1856 \mathrm{E}$ & 800 to $1,800 \mathrm{~m}$ & $10,12,16,17,33$ \\
\hline Thamnomanes caesius (Temminck, 1820) & Below $400 \mathrm{~m}$ & 3,33 \\
\hline Myrmotherula gularis (Spix, 1825) E & To $1,500 \mathrm{~m}$ & $\begin{array}{l}1,2,6,7,8,11,13,14,17,21,22,24,27,28 \\
31,33\end{array}$ \\
\hline Myrmotherula axillaris (Vieillot, 1817) & To $600 \mathrm{~m}$ & $1,2,4,7,33$ \\
\hline Myrmotherula minor Salvadori, $1864 \mathrm{E}, \mathrm{A}$ & 300 to $800 \mathrm{~m}$ & 33 \\
\hline Myrmotherula unicolor (Ménétriès, 1835) E & To $600 \mathrm{~m}$ & $1,2,3,6,7,31,33$ \\
\hline Herpsilochmus rufimarginatus (Temminck, 1822) & To $600 \mathrm{~m}$ & $1,4,5,8,27,33$ \\
\hline Drymophila ferruginea (Temminck, 1822) E & To $1,000 \mathrm{~m}$ & $3,8,11,12,14,17,22,33$ \\
\hline Drymophila rubricollis (Bertoni, 1901) E & 1,200 to $1,700 \mathrm{~m}$ & $13,14,16,17,24,33$ \\
\hline Drymophila genei (Filippi, 1847) E & Above $1,500 \mathrm{~m}$ & 17 \\
\hline Drymophila ochropyga (Hellmayr, 1906) E & 900 to $1,300 \mathrm{~m}$ & $11,13,14,16,17,24,33,34$ \\
\hline Drymophila malura (Temminck, 1825) E & 900 to $1,700 \mathrm{~m}$ & $11,16,23,24,33$ \\
\hline Drymophila squamata (Lichtenstein, 1823) E & To $600 \mathrm{~m}$ & $1,2,4,6,7,27,33$ \\
\hline Terenura maculata (Wied, 1831) E & To $1,000 \mathrm{~m}$ & $2,6,7,8,15,21,27,31,33$ \\
\hline Pyriglena leucoptera (Vieillot, 1818) E & To $1,800 \mathrm{~m}$ & $\begin{array}{l}2,4,5,7,9,10,11,13,14,17,21,23,24,29 \\
30,32,33,34\end{array}$ \\
\hline Myrmeciza loricata (Lichtenstein, 1823) E & To $1,200 \mathrm{~m}$ & $3,10,11,13,14,16,22,33,34$ \\
\hline \multicolumn{3}{|l|}{ Conopophagidae } \\
\hline Conopophaga lineata (Wied, 1831) E & 300 to $2,000 \mathrm{~m}$ & $6,8,9,10,11,12,14,16,17,20,23,24,33,34$ \\
\hline Conopophaga melanops (Vieillot, 1818) E & To $800 \mathrm{~m}$ & $1,4,6,7,8,12,21,33$ \\
\hline \multicolumn{3}{|l|}{ Grallariidae } \\
\hline Grallaria varia (Boddaert, 1783) & To $1,800 \mathrm{~m}$ & $2,6,10,11,16,17,24,33$ \\
\hline \multicolumn{3}{|l|}{ Rhinocryptidae } \\
\hline Psilorhamphus guttatus (Ménétriès, 1835) E & To $1,500 \mathrm{~m}$ & $2,7,11,14,17,33,34$ \\
\hline Merulaxis ater Lesson, $1830 \mathrm{E}$ & To $1,200 \mathrm{~m}$ & 27,33 \\
\hline
\end{tabular}


Appendix. Continued.

\begin{tabular}{|c|c|c|}
\hline Species & Altitudinal range & Localities \\
\hline $\begin{array}{l}\text { Scytalopus notorius Raposo, Stopiglia, Loskot \& } \\
\text { Kirwan, } 2006 \text { E }\end{array}$ & 900 to $2,100 \mathrm{~m}$ & $10,16,17,23,26,33$ \\
\hline Scytalopus indigoticus (Wied, 1831) E & 800 to $1,200 \mathrm{~m}$ & 11,14 \\
\hline \multicolumn{3}{|l|}{ Formicariidae } \\
\hline Formicarius colma Boddaert, 1783 & To $900 \mathrm{~m}$ & $1,2,6,7,12,21,33$ \\
\hline Chamaeza campanisona (Lichtenstein, 1823) & 300 to $1,000 \mathrm{~m}$ & $8,12,13,15,33$ \\
\hline Chamaeza meruloides Vigors, $1825 \mathrm{E}$ & 800 to $1,200 \mathrm{~m}$ & $9,11,12,13,14,16,22,33$ \\
\hline Chamaeza ruficauda (Cabanis \& Heine, 1859) E & 1,000 to $2,000 \mathrm{~m}$ & $10,16,17,23,33$ \\
\hline \multicolumn{3}{|l|}{ Scleruridae } \\
\hline Sclerurus mexicanus Sclater, 1857 A & Below $200 \mathrm{~m}$ & 1 \\
\hline Sclerurus scansor (Ménétriès, 1835) E & To $1,500 \mathrm{~m}$ & $6,10,11,12,13,17,21,24,31,33$ \\
\hline \multicolumn{3}{|l|}{ Dendrocolaptidae } \\
\hline Dendrocincla turdina (Lichtenstein, 1820) E & To $900 \mathrm{~m}$ & $1,2,6,12,31,33$ \\
\hline Sittasomus griseicapillus (Vieillot, 1818) & To $1,800 \mathrm{~m}$ & $\begin{array}{l}1,2,6,7,10,11,12,13,17,20,21,22,24,28 \\
33,34\end{array}$ \\
\hline Xiphocolaptes albicollis (Vieillot, 1818) & To $1,800 \mathrm{~m}$ & $1,2,6,10,11,13,17,21,22,23,24,27,33,34$ \\
\hline Dendrocolaptes platyrostris Spix, 1825 & 300 to $1,200 \mathrm{~m}$ & $6,10,14,17,33$ \\
\hline Xiphorhynchus fuscus (Vieillot, 1818) E & To $1,500 \mathrm{~m}$ & $\begin{array}{l}1,2,6,8,10,11,12,13,16,17,21,22,24,27 \\
31,32,33,34\end{array}$ \\
\hline Lepidocolaptes squamatus (Lichtenstein, 1822) E & To $1,800 \mathrm{~m}$ & $6,10,11,12,13,14,16,17,31,33,34$ \\
\hline Campylorhamphus falcularius (Vieillot, 1822) E & To $1,800 \mathrm{~m}$ & $2,6,10,15,16,17,27,33,34$ \\
\hline \multicolumn{3}{|l|}{ Furnariidae } \\
\hline Furnarius figulus (Lichtenstein, 1823) & To $1,000 \mathrm{~m}$ & $2,11,18,19,20,31$ \\
\hline Furnarius rufus (Gmelin, 1788) & To $1,800 \mathrm{~m}$ & $2,4,5,9,11,16,19,20,21,24,26,29,31,34$ \\
\hline Oreophylax moreirae (Miranda Ribeiro, 1906) E & Above $1,950 \mathrm{~m}$ & 17 \\
\hline Synallaxis ruficapilla Vieillot, $1819 \mathrm{E}$ & To $1,800 \mathrm{~m}$ & $3,6,8,10,11,12,13,16,17,20,23,24,33,34$ \\
\hline Synallaxis cinerascens Temminck, 1823 & 900 to $1,200 \mathrm{~m}$ & 16,24 \\
\hline Synallaxis albescens Temminck, 1823 & $\begin{array}{l}\text { Few records at about } \\
1,000 \mathrm{~m}\end{array}$ & 9 \\
\hline Synallaxis spixi Sclater, 1856 & To $2,100 \mathrm{~m}$ & $\begin{array}{l}1,4,5,8,9,11,13,16,17,19,20,22,23,26 \\
28,29,30,33,34\end{array}$ \\
\hline Cranioleuca pallida (Wied, 1831) E & 400 to $2,000 \mathrm{~m}$ & $\begin{array}{l}9,10,11,13,14,16,17,19,20,23,24,27,33 \\
34\end{array}$ \\
\hline Certhiaxis cinnamomeus (Gmelin, 1788) & To $1,000 \mathrm{~m}$ & 1,20 \\
\hline Phacellodomus rufifrons (Wied, 1821) & To $1,300 \mathrm{~m}$ & $1,9,11,20,24,25,29,34$ \\
\hline Phacellodomus erythrophthalmus (Wied, 1821) E & To $1,800 \mathrm{~m}$ & $2,11,12,14,16,17,20,21,24,29,30$ \\
\hline Anumbius annumbi (Vieillot, 1817) & $\begin{array}{l}\text { Few records at about } \\
1,000 \mathrm{~m}\end{array}$ & 9,20 \\
\hline Anabacerthia amaurotis (Temminck, 1823) E & 300 to $1,500 \mathrm{~m}$ & $3,10,12,13,14,17,33$ \\
\hline Syndactyla rufosuperciliata (Lafresnaye, 1832) & 300 to $2,000 \mathrm{~m}$ & $6,10,11,13,14,16,17,20,24,33,34$ \\
\hline Philydor lichtensteini Cabanis \& Heine, 1859 E & To $900 \mathrm{~m}$ & $2,6,8,13,33$ \\
\hline Philydor atricapillus (Wied, 1821) E & To $1,300 \mathrm{~m}$ & $1,2,3,6,7,10,12,17,27,33$ \\
\hline Philydor rufum (Vieillot, 1818) & To $1,500 \mathrm{~m}$ & $\begin{array}{l}1,2,6,7,8,10,11,12,13,14,16,17,21,27 \\
31,33,34\end{array}$ \\
\hline Anabazenops fuscus (Vieillot, 1816) E & 300 to $1,800 \mathrm{~m}$ & $6,7,9,10,11,12,14,16,17,22,24,33,34$ \\
\hline Cichlocolaptes leucophrus (Jardine \& Selby, 1830) E & To $1,500 \mathrm{~m}$ & $1,2,6,7,10,11,12,13,17,24,31,33$ \\
\hline
\end{tabular}


Appendix. Continued.

\begin{tabular}{|c|c|c|}
\hline Species & Altitudinal range & Localities \\
\hline Automolus leucophthalmus (Wied, 1821) E & To $900 \mathrm{~m}$ & $1,2,4,6,7,8,12,13,21,22,27,33$ \\
\hline Lochmias nematura (Lichtenstein, 1823 & To $2,100 \mathrm{~m}$ & $\begin{array}{l}1,6,8,9,10,11,12,13,16,17,22,23,24 \\
26,30,33,34\end{array}$ \\
\hline Heliobletus contaminatus Berlepsch, $1885 \mathrm{E}$ & 800 to $1,800 \mathrm{~m}$ & $10,11,12,17,24$ \\
\hline Xenops minutus (Sparrman, 1788) & To $1,000 \mathrm{~m}$ & $1,2,6,7,8,11,12,14,21,22,31,33,34$ \\
\hline Xenops rutilans Temminck, 1821 & To $1,500 \mathrm{~m}$ & $1,2,6,7,10,11,12,13,17,24,31,33,34$ \\
\hline \multicolumn{3}{|l|}{ Tyrannidae } \\
\hline Mionectes oleagineus (Lichtenstein, 1823) & To $600 \mathrm{~m}$ & $1,2,4,6,8,33$ \\
\hline Mionectes rufiventris Cabanis, $1846 \mathrm{E}$ & To $1,800 \mathrm{~m}$ & $2,6,7,10,11,12,13,16,17,21,27,33,34$ \\
\hline Leptopogon amaurocephalus Tschudi, 1846 & To $1,500 \mathrm{~m}$ & $\begin{array}{l}1,2,6,7,8,10,11,12,13,16,17,21,27,31 \\
33,34\end{array}$ \\
\hline Corythopis delalandi (Lesson, 1830) & To $600 \mathrm{~m}$ & $1,6,31,33$ \\
\hline Hemitriccus diops (Temminck, 1822) E & 1,000 to $1,500 \mathrm{~m}$ & $10,11,12,13,17,20,24,33,34$ \\
\hline Hemitriccus orbitatus (Wied, 1831) E & To $1,000 \mathrm{~m}$ & $1,2,4,6,7,8,13,21,31,33$ \\
\hline Hemitriccus nidipendulus (Wied, 1831) E & To $1,000 \mathrm{~m}$ & $8,11,14,20,33,34$ \\
\hline Myiornis auricularis (Vieillot, 1818) & To $1,500 \mathrm{~m}$ & $3,7,8,10,11,12,14,17,28,33$ \\
\hline Poecilotriccus plumbeiceps (Lafresnaye, 1846) & 500 to $1,800 \mathrm{~m}$ & $9,10,11,13,16,17,20,23,24,29,30,33,34$ \\
\hline Todirostrum poliocephalum (Wied, 1831) E & To $1,300 \mathrm{~m}$ & $1,2,4,8,11,16,20,29,30$ \\
\hline Todirostrum cinereum (Linnaeus, 1766) & To $1,000 \mathrm{~m}$ & $2,3,20$ \\
\hline Phyllomyias burmeisteri Cabanis \& Heine, 1859 & To $1,500 \mathrm{~m}$ & $2,6,7,10,12,14,16,17,27,31,33,34$ \\
\hline Phyllomyias virescens (Temminck, 1824) E & 800 to $1,300 \mathrm{~m}$ & 11,16 \\
\hline Phyllomyias fasciatus (Thunberg, 1822) & To $1,800 \mathrm{~m}$ & $\begin{array}{l}2,5,6,7,10,11,12,13,14,16,17,24,29 \\
30,33,34\end{array}$ \\
\hline Phyllomyias griseocapilla Sclater, $1862 \mathrm{E}$ & 500 to $1,800 \mathrm{~m}$ & $6,7,10,11,12,13,14,16,17,23,24,33,34$ \\
\hline Elaenia flavogaster (Thunberg, 1822) & To $1,800 \mathrm{~m}$ & $\begin{array}{l}2,4,5,6,8,9,11,13,16,19,20,23,25,31 \\
32,33,34\end{array}$ \\
\hline Elaenia albiceps (d'Orbigny \& Lafresnaye, 1837) & $\begin{array}{l}\text { One record at about } 1,000 \\
\mathrm{~m}\end{array}$ & 15 \\
\hline Elaenia parvirostris Pelzeln, 1868 & One record at about $900 \mathrm{~m}$ & 34 \\
\hline Elaenia mesoleuca (Deppe, 1830) & 800 to $1,800 \mathrm{~m}$ & $11,13,14,16,23,33$ \\
\hline Elaenia obscura (d'Orbigny \& Lafresnaye, 1837) & 800 to $2,100 \mathrm{~m}$ & $11,13,14,17,20,26,34$ \\
\hline Ornithion inerme Hartlaub, $1853 \mathrm{~A}$ & One record at about $400 \mathrm{~m}$ & 33 \\
\hline Camptostoma obsoletum (Temminck, 1824) & To $1,800 \mathrm{~m}$ & $\begin{array}{l}2,4,5,6,8,9,10,11,12,16,17,19,20,23 \\
33,34\end{array}$ \\
\hline Serpophaga nigricans (Vieillot, 1817) & 800 to $1,200 \mathrm{~m}$ & $9,11,20$ \\
\hline Serpophaga subcristata (Vieillot, 1817) & 300 to $1,300 \mathrm{~m}$ & $11,19,20,29,30,31,33,34$ \\
\hline Capsiempis flaveola (Lichtenstein, 1823) & 300 to $900 \mathrm{~m}$ & $8,11,33$ \\
\hline Phylloscartes ventralis (Temminck, 1824) & 800 to $2,100 \mathrm{~m}$ & $10,11,12,13,14,16,17,22,23,25,33,34$ \\
\hline Phylloscartes paulista Ihering \& Ihering, 1907 E, A & One record at about $400 \mathrm{~m}$ & 33 \\
\hline Phylloscartes oustaleti (Sclater, 1887) E, A & 300 to $800 \mathrm{~m}$ & 33 \\
\hline Phylloscartes difficilis (Ihering \& Ihering, 1907) E & 800 to $2,100 \mathrm{~m}$ & $17,23,26,33$ \\
\hline Rhynchocyclus olivaceus (Temminck, 1820) A & Below $200 \mathrm{~m}$ & 1,2 \\
\hline Tolmomyias sulphurescens (Spix, 1825) & To $1,700 \mathrm{~m}$ & $\begin{array}{l}1,2,6,7,9,10,11,13,14,16,17,20,21,22 \\
23,24,25,27,28,29,30,31,33,34\end{array}$ \\
\hline Tolmomyias flaviventris (Wied, 1831) & Below $200 \mathrm{~m}$ & $1,5,33$ \\
\hline
\end{tabular}


Appendix. Continued.

\begin{tabular}{|c|c|c|}
\hline Species & Altitudinal range & Localities \\
\hline Platyrinchus mystaceus Vieillot, 1818 & To $1,500 \mathrm{~m}$ & $\begin{array}{l}2,3,6,7,8,10,11,12,13,16,17,22,24,27 \\
33,34\end{array}$ \\
\hline Platyrinchus leucoryphus Wied, 1831 A & To $400 \mathrm{~m}$ & 1,33 \\
\hline Myiophobus fasciatus (Statius Muller, 1776) & To $1,200 \mathrm{~m}$ & $1,4,5,8,9,11,13,20,24,28,29,32,33,34$ \\
\hline Myiobius barbatus (Gmelin, 1789) & To $900 \mathrm{~m}$ & $1,2,3,6,7,11,12,33$ \\
\hline Myiobius atricaudus Lawrence, 1863 & 900 to $1,100 \mathrm{~m}$ & $13,14,24,33$ \\
\hline Hirundinea ferruginea (Gmelin, 1788) & To $1,200 \mathrm{~m}$ & $6,7,9,11,12,16,19,28,33,34$ \\
\hline Lathrotriccus euleri (Cabanis, 1868) & To $1,800 \mathrm{~m}$ & $\begin{array}{l}1,2,4,6,7,9,10,11,12,13,16,17,23,24 \\
28,31,33,34\end{array}$ \\
\hline Cnemotriccus fuscatus (Wied, 1831) & Below $200 \mathrm{~m}$ & 1,33 \\
\hline Contopus cooperi (Nuttall, 1831) & One record at about $400 \mathrm{~m}$ & 33 \\
\hline Contopus cinereus (Spix, 1825) & To $1,000 \mathrm{~m}$ & $1,2,7,8,11,33,34$ \\
\hline Pyrocephalus rubinus (Boddaert, 1783) & 900 to $1,800 \mathrm{~m}$ & 17,18 \\
\hline Knipolegus cyanirostris (Vieillot, 1818) & 500 to $2,100 \mathrm{~m}$ & $12,13,14,15,16,17,24,25,26,33$ \\
\hline Knipolegus lophotes Boie, 1828 & At $1,000 \mathrm{~m}$ & $2,7,9,33$ \\
\hline Knipolegus nigerrimus (Vieillot, 1818) E & $400 \mathrm{~m}$ to $2,100 \mathrm{~m}$ & $6,8,10,16,17,26,33$ \\
\hline Satrapa icterophrys (Vieillot, 1818) & To $1,000 \mathrm{~m}$ & $11,13,18,33,34$ \\
\hline Xolmis cinereus (Vieillot, 1816) & 800 to $1,000 \mathrm{~m}$ & 18,19 \\
\hline Xolmis velatus (Lichtenstein, 1823) & To $1,800 \mathrm{~m}$ & $2,9,20,23,26$ \\
\hline Gubernetes yetapa (Vieillot, 1818) & $\begin{array}{l}\text { Few records between } 900 \\
\text { and } 1,000 \mathrm{~m}\end{array}$ & 20 \\
\hline Muscipipra vetula (Lichtenstein, 1823) E & 800 to $1,800 \mathrm{~m}$ & $9,11,12,16,17,26,34$ \\
\hline Fluvicola nengeta (Linnaeus, 1766) & To $1,200 \mathrm{~m}$ & $4,5,11,16,18,19,20,27,31,34$ \\
\hline Arundinicola leucocephala (Linnaeus, 1764) & Below $200 \mathrm{~m}$ & 2 \\
\hline Colonia colonus (Vieillot, 1818) & 300 to $1,200 \mathrm{~m}$ & $7,8,11,13,16,20,33,34$ \\
\hline Machetornis rixosa (Vieillot, 1819) & To $1,100 \mathrm{~m}$ & $2,3,11,19,20,24,34$ \\
\hline Legatus leucophaius (Vieillot, 1818) & To $600 \mathrm{~m}$ & $2,3,6,7,8,33$ \\
\hline Myiozetetes cayanensis (Linnaeus, 1766) & 200 to $1,800 \mathrm{~m}$ & $8,9,11,16,17,33$ \\
\hline Myiozetetes similis (Spix, 1825) & To $1,800 \mathrm{~m}$ & $\begin{array}{l}2,4,5,6,7,8,9,10,11,16,17,19,23,24 \\
25,27,28,29,30,31,32,33,34\end{array}$ \\
\hline Pitangus sulphuratus (Linnaeus, 1766) & To $1,800 \mathrm{~m}$ & $\begin{array}{l}1,2,4,5,6,7,9,10,11,16,19,20,21,23 \\
24,25,27,28,29,30,31,32,33,34\end{array}$ \\
\hline Myiodynastes maculatus (Statius Muller, 1776) & To $1,500 \mathrm{~m}$ & $\begin{array}{l}2,6,7,8,9,10,11,12,13,14,16,17,19,22 \\
33,34\end{array}$ \\
\hline Megarynchus pitangua (Linnaeus, 1766) & To $1,800 \mathrm{~m}$ & $\begin{array}{l}2,4,6,7,8,9,10,11,13,16,19,20,21,23 \\
24,25,27,28,31,33,34\end{array}$ \\
\hline Empidonomus varius (Vieillot, 1818) & To $1,300 \mathrm{~m}$ & $2,6,11,12,13,16,19,21,24,25,33,34$ \\
\hline Tyrannus melancholicus Vieillot, 1819 & To $1,800 \mathrm{~m}$ & $\begin{array}{l}2,4,5,6,7,9,11,12,13,16,19,20,21,23 \\
24,27,28,31,34\end{array}$ \\
\hline Tyrannus savana Vieillot, 1808 & To $1,000 \mathrm{~m}$ & $5,6,11,18,19,34$ \\
\hline Rhytipterna simplex (Lichtenstein, 1823) & To $1,000 \mathrm{~m}$ & $1,2,6,12,33$ \\
\hline Sirystes sibilator (Vieillot, 1818) & 300 to $1,000 \mathrm{~m}$ & $11,12,33$ \\
\hline Myiarchus tuberculifer (d'Orbigny \& Lafresnaye, 1837) & To $700 \mathrm{~m}$ & $1,2,6,8,31,33$ \\
\hline Myiarchus swainsoni Cabanis \& Heine, 1859 & 700 to $1,300 \mathrm{~m}$ & $11,12,13,16,20,33,34$ \\
\hline Myiarchus ferox (Gmelin, 1789) & To $1,800 \mathrm{~m}$ & $5,9,11,20,21,24,26,33$ \\
\hline
\end{tabular}


Appendix. Continued.

\begin{tabular}{|c|c|c|}
\hline Species & Altitudinal range & Localities \\
\hline Ramphotrigon megacephalum (Swainson, 1835) & To $1,100 \mathrm{~m}$ & $2,8,10,11,14,33$ \\
\hline Attila phoenicurus Pelzeln, 1868 & 800 to $1,100 \mathrm{~m}$ & $10,13,14,24$ \\
\hline Attila rufus (Vieillot, 1819) E & To $1,500 \mathrm{~m}$ & $\begin{array}{l}1,2,4,6,7,8,10,11,12,13,16,17,21,22,31, \\
32,33\end{array}$ \\
\hline \multicolumn{3}{|l|}{ Cotingidae } \\
\hline Phibalura flavirostris Vieillot, $1816 \mathrm{~A}$ & 500 to $1,800 \mathrm{~m}$ & $11,12,16,17,26,33$ \\
\hline Carpornis cucullata (Swainson, 1821) E & 800 to $1,800 \mathrm{~m}$ & $10,12,13,15,17,24,33$ \\
\hline Carpornis melanocephala (Wied, 1820) E, A & Below $200 \mathrm{~m}$ & 1 \\
\hline Procnias nudicollis (Vieillot, 1817) E, A & To $1,800 \mathrm{~m}$ & $1,2,6,11,12,14,17,22,24,33$ \\
\hline Tijuca atra Ferrusac, 1829 E & 300 to $1,800 \mathrm{~m}$ & $11,17,24,26,33$ \\
\hline Tijuca condita Snow, 1980 E, A & Above $1,800 \mathrm{~m}$ & 17 \\
\hline Calyptura cristata (Vieillot, 1818) E, A & One record at $550 \mathrm{~m}$ & 6 \\
\hline Pyroderus scutatus (Shaw, 1792) A & To $600 \mathrm{~m}$ & 33 \\
\hline \multicolumn{3}{|l|}{ Pipridae } \\
\hline Neopelma aurifrons (Wied, 1831) E, A & Below $200 \mathrm{~m}$ & 1 \\
\hline Neopelma chrysolophum Pinto, 1944 E & Above $800 \mathrm{~m}$ & $11,16,17,23$ \\
\hline Piprites chloris (Temminck, 1822) & One record at $500 \mathrm{~m}$ & 33 \\
\hline Ilicura militaris (Shaw \& Nodder, 1809) E & To $1,500 \mathrm{~m}$ & $5,6,10,11,12,13,14,17,22,33,34$ \\
\hline Machaeropterus regulus (Hahn, 1819) & To $600 \mathrm{~m}$ & 1,33 \\
\hline Manacus manacus Linnaeus, 1766) & To $1,100 \mathrm{~m}$ & $1,2,4,6,8,11,14,21,32,33$ \\
\hline Chiroxiphia caudata (Shaw \& Nodder, 1793) E & To $1,800 \mathrm{~m}$ & $\begin{array}{l}1,2,4,6,7,10,11,12,13,14,16,17,20,21 \\
22,24,27,31,33,34\end{array}$ \\
\hline \multicolumn{3}{|l|}{ Tityridae } \\
\hline Oxyruncus cristatus Swainson, 1821 & To $1,800 \mathrm{~m}$ & $6,10,11,12,13,14,17,33$ \\
\hline Schiffornis virescens (Lafresnaye, 1838) E & 800 to $1,500 \mathrm{~m}$ & $11,12,13,17,24,33$ \\
\hline Schiffornis turdina (Wied, 1831) & To $400 \mathrm{~m}$ & $1,2,6,33$ \\
\hline Laniisoma elegans (Thunberg, 1823) E, A & To $1,100 \mathrm{~m}$ & $1,2,3,12,13,33$ \\
\hline Iodopleura pipra (Lesson, 1831) E, A & 300 to $1,000 \mathrm{~m}$ & $3,6,10$ \\
\hline Tityra inquisitor (Lichtenstein, 1823) & To $600 \mathrm{~m}$ & $1,2,33$ \\
\hline Tityra cayana (Linnaeus, 1766) & To $600 \mathrm{~m}$ & $2,3,6,27,28,33$ \\
\hline Pachyramphus viridis (Vieillot, 1816) & To $1,000 \mathrm{~m}$ & $1,2,8,11,12,13,20,33,34$ \\
\hline Pachyramphus castaneus (Jardine \& Selby, 1827) & 300 to $1,800 \mathrm{~m}$ & $\begin{array}{l}2,4,6,7,8,10,11,12,13,14,16,17,27,31, \\
33,34\end{array}$ \\
\hline Pachyramphus polychopterus (Vieillot, 1818) & To $1,800 \mathrm{~m}$ & $\begin{array}{l}1,4,5,6,7,9,11,12,13,16,17,21,22,23,24, \\
31,33,34\end{array}$ \\
\hline Pachyramphus marginatus (Lichtenstein, 1823) & To $600 \mathrm{~m}$ & $1,2,4,6,7,31,33$ \\
\hline Pachyramphus validus (Lichtenstein, 1823) & To $1,000 \mathrm{~m}$ & $1,2,4,6,7,8,11,12,14,33,34$ \\
\hline \multicolumn{3}{|l|}{ Vireonidae } \\
\hline Cyclarhis gujanensis (Gmelin, 1789) & To $2,000 \mathrm{~m}$ & $\begin{array}{l}2,6,7,8,9,10,11,13,14,16,17,22,23,24, \\
25,26,27,29,30,33,34\end{array}$ \\
\hline Vireo olivaceus (Linnaeus, 1766) & To $1,300 \mathrm{~m}$ & $1,2,4,6,7,8,10,11,12,21,22,25,31,33,34$ \\
\hline Hylophilus poicilotis Temminck, $1822 \mathrm{E}$ & $700 \mathrm{~m}$ to $1,600 \mathrm{~m}$ & $6,10,11,12,13,16,17,22,23,24,26,33,34$ \\
\hline Hylophilus amaurocephalus (Nordmann, 1835) & 850 to $1,000 \mathrm{~m}$ & 11,20 \\
\hline Hylophilus thoracicus Temminck, 1822 & To $400 \mathrm{~m}$ & $1,4,5,8$ \\
\hline \multicolumn{3}{|l|}{ Corvidae } \\
\hline Cyanocorax cristatellus (Temminck, 1823) & 800 to $1,000 \mathrm{~m}$ & 9,34 \\
\hline
\end{tabular}


Appendix. Continued.

\begin{tabular}{|c|c|c|}
\hline Species & Altitudinal range & Localities \\
\hline \multicolumn{3}{|l|}{ Hirundinidae } \\
\hline Pygochelidon cyanoleuca (Vieillot, 1817) & To $2,000 \mathrm{~m}$ & $\begin{array}{l}2,4,5,6,7,9,10,11,13,16,17,19,20,21,27 \\
29,30,31,33,34\end{array}$ \\
\hline Alopochelidon fucata (Temminck, 1822) & $\begin{array}{l}\text { One record at about } \\
1,000 \mathrm{~m}\end{array}$ & 20 \\
\hline Atticora tibialis (Cassin, 1853) & To $500 \mathrm{~m}$ & $1,2,7,33$ \\
\hline Stelgidopteryx ruficollis (Vieillot, 1817) & To $1,300 \mathrm{~m}$ & $2,4,5,6,7,8,9,11,13,20,21,29,30,33,34$ \\
\hline Progne tapera (Vieillot, 1817) & To $1,300 \mathrm{~m}$ & $1,9,11,18,20,29,30,33,34$ \\
\hline Progne chalybea (Gmelin, 1789) & To $1,000 \mathrm{~m}$ & $1,3,19,20,33$ \\
\hline Tachycineta leucorrhoa (Vieillot, 1817) & To $1,000 \mathrm{~m}$ & $2,8,18,20,33$ \\
\hline Hirundo rustica Linnaeus, 1758 & To $1,000 \mathrm{~m}$ & $1,2,5,18$ \\
\hline \multicolumn{3}{|l|}{ Troglodytidae } \\
\hline Troglodytes musculus Naumann, 1823 & To $1,800 \mathrm{~m}$ & $\begin{array}{l}2,4,5,6,7,9,11,12,13,16,17,19,20,21,23 \\
24,27,28,29,30,31,33,34\end{array}$ \\
\hline Pheugopedius genibarbis Swainson, 1838 & To $600 \mathrm{~m}$ & $1,2,8,31,33$ \\
\hline Cantorchilus longirostris (Vieillot, 1819) & To $600 \mathrm{~m}$ & $1,8,21,32,33$ \\
\hline \multicolumn{3}{|l|}{ Polioptilidae } \\
\hline Ramphocaenus melanurus Vieillot, 1819 A & Recorded at about $400 \mathrm{~m}$ & 33 \\
\hline \multicolumn{3}{|l|}{ Turdidae } \\
\hline Turdus flavipes Vieillot, 1818 & To $2,000 \mathrm{~m}$ & $\begin{array}{l}2,4,6,7,10,11,12,13,14,16,17,24,31,32 \\
33,34\end{array}$ \\
\hline Turdus rufiventris Vieillot, 1818 & To $2,000 \mathrm{~m}$ & $\begin{array}{l}1,2,4,5,6,7,9,10,11,13,14,16,17,19,20 \\
21,22,24,27,28,29,30,31,32,33,34\end{array}$ \\
\hline Turdus leucomelas Vieillot, 1818 & To $1,100 \mathrm{~m}$ & $\begin{array}{l}1,2,4,5,6,7,9,10,11,12,13,16,19,22,24 \\
27,31,33,34\end{array}$ \\
\hline Turdus amaurochalinus Cabanis, 1850 & To $2,000 \mathrm{~m}$ & $5,10,11,13,17,19,33,34$ \\
\hline Turdus subalaris (Seebohm, 1887) & To $1,000 \mathrm{~m}$ & 10,33 \\
\hline Turdus albicollis Vieillot, 1818 & To $2,000 \mathrm{~m}$ & $1,6,7,8,10,11,12,13,16,17,27,31,33,34$ \\
\hline \multicolumn{3}{|l|}{ Mimidae } \\
\hline Mimus saturninus (Lichtenstein, 1823) & To $1,100 \mathrm{~m}$ & $2,5,9,11,19,21,24,29,33,34$ \\
\hline \multicolumn{3}{|l|}{ Motacillidae } \\
\hline Anthus lutescens Pucheran, 1855 & To $1,000 \mathrm{~m}$ & $1,2,5,20$ \\
\hline \multicolumn{3}{|l|}{ Coerebidae } \\
\hline Coereba flaveola (Linnaeus, 1758) & To $1,000 \mathrm{~m}$ & $1,2,4,6,7,8,9,10,11,12,19,27,31,33,34$ \\
\hline \multicolumn{3}{|l|}{ Thraupidae } \\
\hline Saltator fuliginosus (Daudin, 1800) E & To $1,000 \mathrm{~m}$ & $5,6,7,11,15,27,33$ \\
\hline Saltator maximus (Statius Muller, 1776) & To $500 \mathrm{~m}$ & $1,2,4,5,7,8,33$ \\
\hline Saltator similis d'Orbigny \& Lafresnaye, 1837 & 300 to $2,000 \mathrm{~m}$ & $6,10,11,12,14,16,17,20,31,33,34$ \\
\hline Saltator maxillosus Cabanis, $1851 \mathrm{E}$ & 900 to $2,100 \mathrm{~m}$ & $11,16,17$ \\
\hline Orchesticus abeillei (Lesson, 1839) E & 500 to $1,500 \mathrm{~m}$ & $6,10,11,12,13,15,17,33$ \\
\hline Schistochlamys ruficapillus (Vieillot, 1817) & 800 to $2,100 \mathrm{~m}$ & $9,11,12,16,17,20,26,29,34$ \\
\hline Cissops leverianus (Gmelin, 1788) & Recorded at about $800 \mathrm{~m}$ & 33 \\
\hline Nemosia pileata (Boddaert, 1783) & Below 200 m & 1,5 \\
\hline Orthogonys chloricterus (Vieillot, 1819) E & To $1,000 \mathrm{~m}$ & $2,6,7,8,13,31,33$ \\
\hline Thlypopsis sordida (d’Orbigny \& Lafresnaye, 1837) & To $1,000 \mathrm{~m}$ & 12,32 \\
\hline
\end{tabular}


Appendix. Continued.

\begin{tabular}{|c|c|c|}
\hline Species & Altitudinal range & Localities \\
\hline Pyrrhocoma ruficeps (Strickland, 1844) E & 800 to $1,800 \mathrm{~m}$ & $13,16,17,33$ \\
\hline Trichothraupis melanops (Vieillot, 1818) & To $1,800 \mathrm{~m}$ & $\begin{array}{l}2,6,7,10,11,12,13,16,17,21,22,24,27,29,30 \\
31,33,34\end{array}$ \\
\hline Tachyphonus cristatus (Linnaeus, 1766) & To $600 \mathrm{~m}$ & $1,2,6,7,8,21,31,33$ \\
\hline Tachyphonus coronatus (Vieillot, 1822) E & To $1,000 \mathrm{~m}$ & $\begin{array}{l}2,4,6,7,8,9,10,11,12,13,14,19,21,22,27,28 \\
33,34\end{array}$ \\
\hline Ramphocelus bresilius (Linnaeus, 1766) E & To $1,300 \mathrm{~m}$ & $1,2,8,11,25,29,30,31,32,33$ \\
\hline Thraupis sayaca (Linnaeus, 1766) & To $1,800 \mathrm{~m}$ & $\begin{array}{l}2,5,6,7,9,10,11,16,19,20,21,22,24,25,26 \\
27,28,31,33,34\end{array}$ \\
\hline Thraupis cyanoptera (Vieillot, 1817) E & To $1,800 \mathrm{~m}$ & $2,6,7,10,11,12,13,17,33,34$ \\
\hline Thraupis ornata (Sparrman, 1789) E & To $1,800 \mathrm{~m}$ & $2,5,6,7,8,10,11,12,14,16,17,19,24,25,33,34$ \\
\hline Thraupis palmarum (Wied, 1823) & To $1,300 \mathrm{~m}$ & $1,2,4,6,8,10,11,16,19,25,33,34$ \\
\hline Stephanophorus diadematus (Temminck, 1823) & 1,200 to $2,100 \mathrm{~m}$ & $17,23,26$ \\
\hline Pipraeidea melanonota (Vieillot, 1819) & To $1,800 \mathrm{~m}$ & $8,10,11,12,13,17,19,31,33,34$ \\
\hline Tangara brasiliensis (Linnaeus, 1766) E, A & To $600 \mathrm{~m}$ & $2,4,5,6,8,33$ \\
\hline Tangara seledon (Statius Muller, 1776) E & To $600 \mathrm{~m}$ & $1,2,6,7,8,21,27,31,33$ \\
\hline Tangara cyanocephala (Statius Muller, 1776) E & To $600 \mathrm{~m}$ & $2,6,7,8,21,28,33$ \\
\hline Tangara desmaresti (Vieillot, 1819) E & To $2,000 \mathrm{~m}$ & $\begin{array}{l}2,6,7,9,10,11,12,13,14,16,17,19,22,23,26 \\
29,30,33,34\end{array}$ \\
\hline Tangara cyanoventris (Vieillot, 1819) E & 300 to $1,000 \mathrm{~m}$ & 20,33 \\
\hline Tangara cayana (Linnaeus, 1766) & To $2,000 \mathrm{~m}$ & $6,9,10,11,12,16,19,20,21,23,25,29,30,33,34$ \\
\hline Tersina viridis (Illiger, 1811) & 300 to $1,000 \mathrm{~m}$ & $6,9,10,11,19,20,34$ \\
\hline Dacnis nigripes Pelzeln, $1856 \mathrm{E}, \mathrm{A}$ & To $1,000 \mathrm{~m}$ & $6,16,33$ \\
\hline Dacnis cayana (Linnaeus, 1766) & To $1,800 \mathrm{~m}$ & $\begin{array}{l}1,2,4,5,6,7,8,9,10,11,12,17,19,21,23,27 \\
29,30,33,34\end{array}$ \\
\hline Chlorophanes spiza (Linnaeus, 1758) A & To $500 \mathrm{~m}$ & 2,27 \\
\hline Hemithraupis ruficapilla (Vieillot, 1818) E & To $1,200 \mathrm{~m}$ & $2,6,7,10,11,12,16,21,33$ \\
\hline Hemithraupis flavicollis (Vieillot, 1818) & To $500 \mathrm{~m}$ & $1,2,6,7,8,31,33$ \\
\hline Conirostrum speciosum (Temminck, 1824) & To $1,000 \mathrm{~m}$ & $2,5,6,7,9,10,11,31,33,34$ \\
\hline \multicolumn{3}{|l|}{ Emberizidae } \\
\hline Zonotrichia capensis (Statius Muller, 1776) & To $2,100 \mathrm{~m}$ & $\begin{array}{l}4,5,6,9,10,11,12,16,17,20,21,22,23,24,26 \\
29,33,34\end{array}$ \\
\hline Ammodramus humeralis (Bosc, 1792) & To $1,000 \mathrm{~m}$ & $2,5,9,16,20$ \\
\hline Haplospiza unicolor Cabanis, $1851 \mathrm{E}$ & To $2,000 \mathrm{~m}$ & $6,8,9,10,11,13,16,17,19,33,34$ \\
\hline Donacospiza albifrons (Vieillot, 1817) & Above $900 \mathrm{~m}$ & 17,20 \\
\hline Poospiza thoracica (Nordmann, 1835) E & Above $900 \mathrm{~m}$ & 16,17 \\
\hline Sicalis flaveola (Linnaeus, 1766) & To $1,800 \mathrm{~m}$ & $1,9,11,12,19,20,21,24,26,29,31,33,34$ \\
\hline Emberizoides herbicola (Vieillot, 1817) & To $1,000 \mathrm{~m}$ & $2,5,20,21$ \\
\hline Volatinia jacarina (Linnaeus, 1766) & To $1,000 \mathrm{~m}$ & $1,2,4,8,9,11,16,20,22,24,33,34$ \\
\hline Sporophila frontalis (Verreaux, 1869) E, A & 400 to $2,000 \mathrm{~m}$ & $6,10,14,15,17,33$ \\
\hline Sporophila falcirostris (Temminck, 1820) E, A & To $1,500 \mathrm{~m}$ & $6,10,14,17,33$ \\
\hline Sporophila lineola (Linnaeus, 1758) & Below 200 m & 5,33 \\
\hline Sporophila nigricollis (Vieillot, 1823) & To $1,000 \mathrm{~m}$ & 13,33 \\
\hline Sporophila caerulescens (Vieillot, 1823) & To $1,200 \mathrm{~m}$ & $3,7,8,10,11,13,16,19,20,22,24,27,28,29,33,34$ \\
\hline Tiaris fuliginosus (Wied, 1830) & To $1,100 \mathrm{~m}$ & $6,7,8,10,11,14,33$ \\
\hline Arremon semitorquatus Swainson, $1838 \mathrm{E}$ & 300 to $1,100 \mathrm{~m}$ & $8,10,11,12,16,20,31,33,34$ \\
\hline
\end{tabular}


Appendix. Continued.

\begin{tabular}{|c|c|c|}
\hline Species & Altitudinal range & Localities \\
\hline \multicolumn{3}{|l|}{ Cardinalidae } \\
\hline Piranga flava (Vieillot, 1822) & 800 to $1,200 \mathrm{~m}$ & $9,11,16,34$ \\
\hline Habia rubica (Vieillot, 1817) & To $1,300 \mathrm{~m}$ & $1,2,6,7,8,10,12,13,17,21,27,33$ \\
\hline Caryothraustes canadensis (Linnaeus, 1766) & To $600 \mathrm{~m}$ & $1,2,4,6,7,31,33$ \\
\hline Cyanoloxia brissonii (Lichtenstein, 1823) A & 800 to $1,000 \mathrm{~m}$ & 34 \\
\hline \multicolumn{3}{|l|}{ Parulidae } \\
\hline Parula pitiayumi (Vieillot, 1817) & To $1,000 \mathrm{~m}$ & $2,6,7,11,21,27,31,33$ \\
\hline Geothlypis aequinoctialis (Gmelin, 1789) & To $1,300 \mathrm{~m}$ & $2,3,8,11,13,19,20,29,30,34$ \\
\hline Basileuterus culicivorus (Deppe, 1830) & To $1,800 \mathrm{~m}$ & $\begin{array}{l}2,6,7,8,10,11,13,14,16,17,20,22,23,24 \\
25,26,28,29,30,32,33,34\end{array}$ \\
\hline Basileuterus leucoblepharus (Vieillot, 1817) E & 800 to $2,000 \mathrm{~m}$ & $10,11,16,17,23,24,25,26,33$ \\
\hline Phaeothlypis rivularis (Wied, 1821) A & Recorded at about $400 \mathrm{n}$ & 33 \\
\hline \multicolumn{3}{|l|}{ Icteridae } \\
\hline Psarocolius decumanus (Pallas, 1769) & To $1,000 \mathrm{~m}$ & $6,9,10,11,14,16,28,33,34$ \\
\hline Cacicus haemorrhous (Linnaeus, 1766) & To $900 \mathrm{~m}$ & $1,2,4,6,7,8,11,12,31,33,34$ \\
\hline Gnorimopsar chopi (Vieillot, 1819) & To $1,000 \mathrm{~m}$ & $2,9,20$ \\
\hline Chrysomus ruficapillus (Vieillot, 1819) & Below 200 m & 2 \\
\hline Molothrus oryzivorus (Gmelin, 1788) A & 900 to $1,500 \mathrm{~m}$ & 17,18 \\
\hline Molothrus bonariensis (Gmelin, 1789) & To $1,000 \mathrm{~m}$ & $2,4,5,6,8,9,11,19,20,34$ \\
\hline Sturnella superciliaris (Bonaparte, 1850) & To $1,000 \mathrm{~m}$ & $1,2,9$ \\
\hline \multicolumn{3}{|l|}{ Fringillidae } \\
\hline Sporagra magellanica (Vieillot, 1805) & 800 to $1,200 \mathrm{~m}$ & $9,10,11,15,16,19,20,29,34$ \\
\hline Euphonia chlorotica (Linnaeus, 1766) & To $800 \mathrm{~m}$ & $3,19,34$ \\
\hline Euphonia violacea (Linnaeus, 1758) & To $1,000 \mathrm{~m}$ & $1,2,6,8,11,12,31,32,33$ \\
\hline Euphonia chalybea (Mikan, 1825) A & 400 to $1,800 \mathrm{~m}$ & $10,13,17,33$ \\
\hline Euphonia cyanocephala (Vieillot, 1818) A & 400 to $1,800 \mathrm{~m}$ & 17,33 \\
\hline Euphonia xanthogaster Sundevall, 1834 & To $1,000 \mathrm{~m}$ & $1,2,3,6,7,8,10,27,31,33$ \\
\hline Euphonia pectoralis (Latham, 1801) E & To $1,500 \mathrm{~m}$ & $1,2,6,7,10,11,12,13,17,28,31,33,34$ \\
\hline Chlorophonia cyanea (Thunberg, 1822) & To $1,800 \mathrm{~m}$ & $6,10,14,16,17,27,33,34$ \\
\hline \multicolumn{3}{|l|}{ Estrildidae } \\
\hline Estrilda astrild (Linnaeus, 1758) & To $1,100 \mathrm{~m}$ & $4,5,8,9,11,19,20,24,31,34$ \\
\hline \multicolumn{3}{|l|}{ Passeridae } \\
\hline Passer domesticus (Linnaeus, 1758) & To $1,100 \mathrm{~m}$ & $3,5,16,18,19,20,34$ \\
\hline
\end{tabular}

Submitted: 16.VI.2009; Accepted: 01.VII.2010.

Editorial responsibility: Claudio J.B. de Carvalho 